NBER WORKING PAPER SERIES

\title{
THE ROLE OF PARENTAL WEALTH AND INCOME IN FINANCING CHILDREN'S COLLEGE ATTENDANCE AND ITS CONSEQUENCES
}

\author{
V. Joseph Hotz \\ Emily E. Wiemers \\ Joshua Rasmussen \\ Kate Maxwell Koegel \\ Working Paper 25144 \\ http://www.nber.org/papers/w25144 \\ NATIONAL BUREAU OF ECONOMIC RESEARCH \\ 1050 Massachusetts Avenue \\ Cambridge, MA 02138 \\ October 2018
}

This research and the Roster and Transfers Module in the 2013 Wave of the PSID were funded by grant P01AG029409 from the National Institute on Aging. We thank Joe Altonji, Breno Braga, Rajashri Chakrabarti, Jim Heckman, Arnaud Maurel, Adam Kapor, Lance Lochner, participants in seminars at Brown, University of Western Ontario and UCLA, and those at 2016 Population Association of America and Society of Labor Economists Meetings and the PSID Conference on "New Directions in Study of Intergenerational Transfers," the HCEO Conference on "Human Capital Formation and Family Economics," the New York Fed Bank Conference on "Higher Education Financing \& Costs and Returns of Higher Education," and the 2017 Southern Economics Association Meetings for comments on earlier drafts of this paper. The views expressed herein are those of the authors and do not necessarily reflect the views of the National Bureau of Economic Research.

NBER working papers are circulated for discussion and comment purposes. They have not been peer-reviewed or been subject to the review by the NBER Board of Directors that accompanies official NBER publications.

(C) 2018 by V. Joseph Hotz, Emily E. Wiemers, Joshua Rasmussen, and Kate Maxwell Koegel. All rights reserved. Short sections of text, not to exceed two paragraphs, may be quoted without explicit permission provided that full credit, including $\odot$ notice, is given to the source. 
The Role of Parental Wealth and Income in Financing Children's College Attendance and Its Consequences

V. Joseph Hotz, Emily E. Wiemers, Joshua Rasmussen, and Kate Maxwell Koegel

NBER Working Paper No. 25144

October 2018

JEL No. I21,I22,I23

\section{ABSTRACT}

This paper examines the influence of parental wealth and income on children's college attendance and parental financing decisions, graduation, and quality of college attended, and whether parental financing affects the subsequent indebtedness of parents and children. We find that higher levels of parents' wealth and income increase the likelihood that children attend college with financial support relative to not attending college, and that parental wealth increases the likelihood that children graduate from college. We show descriptive evidence that parental support for college increases the subsequent level of housing debt that parents hold but does not reduce student debt for children.

\author{
V. Joseph Hotz \\ Department of Economics \\ Box 90097 \\ Duke University \\ Durham, NC 27708-0097 \\ and NBER \\ hotz@econ.duke.edu \\ Emily E. Wiemers \\ Department of Economics \\ 100 Morrissey Blvd \\ Boston, MA 02125 \\ emily.wiemers@umb.edu
}

\author{
Joshua Rasmussen \\ Department of Economics \\ Department of Economics \\ Durham, NC 27708 \\ United States \\ joshua.rasmussen@duke.edu \\ Kate Maxwell Koegel \\ 213 Social Sciences Building \\ 419 Chapel Drive, Box 90097 \\ Durham, NC 27708-0097 \\ kate.maxwell@duke.edu
}




\section{Introduction}

Parents have long been a primary source of financial support for their children's postsecondary education with some estimates suggesting that parents cover over $30 \%$ of college costs. $^{1}$ In this paper we analyze the role that parental resources play in whether children attend college and whether parents provide financial support, the quality and cost of the college they attend, and whether they graduate, and the implications of college financing decisions for subsequent levels of parental and student debt. The dramatic increases in the costs of a college education in the U.S over the past 30 years $^{2}$ have challenged the ability of parents and children to finance a college degree and decisions about college financing may have long-run impacts on the financial circumstances of both parents and children.

Previous research has focused on the impact of parental resources on their children's college attendance. Earlier work found little evidence that parental income had an independent effect on the likelihood of young adults attending college, especially after accounting for children's ability and academic preparation (Cameron and Heckman, 1998, 2001; Keane and Wolpin, 2001; Cameron and Taber, 2004). But, more recent research documents that the relationship between parental income and the college attendance decisions of children has changed over time, with parental income more likely to be predictive of children going to college, even after controlling for the ability and/or academic preparation of children (Belley and Lochner, 2007; Lochner and Monge-Naranjo, 2011, 2012).

Other studies have examined the impact of parental wealth, most notably housing wealth, on college attendance and other outcomes for young adults (Belley and Lochner, 2007; Lovenheim, 2011; Lovenheim and Reynolds, 2013). Lovenheim (2011) finds that increases in housing wealth during a child's teenage years increase the probability that the child attends college and that these effects are larger after 2000 when home equity loans became more common. Lovenheim and Reynolds (2013) show that among children who go to college, increases in parental housing

\footnotetext{
${ }^{1}$ Based on a survey of college students and their parents in 2017, parents cover $31 \%$ of the cost of their child's college costs, second only to costs covered by scholarships and grants (35\%) (SallieMae, 2017).

${ }^{2}$ Since 1987-88, published college tuition costs (tuition \& fees), adjusting for inflation, have increased an average of $8.8 \%$ per year in public 4-year institutions, $4.4 \%$ in non-profit private 4 -year universities, and $4.0 \%$ in public 2-year colleges (College Board, 2017).
} 
wealth increase the likelihood of their child attending a flagship public university and that children from low-income families are more likely to complete college. Finally, Cooper and Luengo-Prado (2015) show that children of homeowners who live in areas where house prices increased during a child's teenage years are more likely to enroll in college and attend higher ranked colleges, though they are not more likely to graduate.

The premise underlying these papers, and the models of parents' investment in their children's human capital in the presence of credit constraints that motivate them, is that parents use their resources - both income and wealth - to finance their children's college attendance (Keane and Wolpin, 2001; Lochner and Monge-Naranjo, 2011, 2012). There also is a sizable literature on the importance of student loans ${ }^{3}$ and grants-in-aid ${ }^{4}$ in funding college education. It is also well-documented that the debt that students accumulate while attending college persists long after they complete or stop attending college and affects their subsequent labor market choices (Rothstein and Rouse, 2011) and their ability to finance housing and other activities (Mezza et al., 2015; Cooper and Wang, 2014; Bleemer et al., 2017).

However, much less is known about how parents' financing of their children's education affects the subsequent financial situations of parents and children, especially with respect to their respective indebtedness. Two notable exceptions are Lochner, Stinebrickner and Suleymanoglu (2018) who show that parental financial transfers reduce student debt repayment problems in the Canada Student Loan Program, and, Faber and Rich (forthcoming) who show that commuting zones that experienced increases in the rate of college attendance had increases in home foreclosures in subsequent years. Both of these papers highlight important interactions between parental financial support for college and subsequent financial outcomes of both parents and children.

We address three related issues concerning parent's investments in their children's human capital and the consequences of how these investments are financed. First, we examine how both parental income and wealth, as measured by housing wealth, affect the likelihood that children

\footnotetext{
${ }^{3}$ Since 2004, the share of undergraduate students who have taken federal subsidized and unsubsidized student loans has increased from $28 \%$ in the 2004-05 academic year to $36 \%$ in 2014-15, with a decreasing share of students only having subsidized loans (College Board, 2015).

${ }^{4}$ In terms of such grants, in 2015, colleges and universities provide $41 \%$ of such aid, $37 \%$ from federal sources, $14 \%$ from employers and private sources, and 8\% coming from state governments (College Board, 2015).
} 
go to college and how this investment is financed. This issue is similar to that addressed in Lovenheim (2011) and Lovenheim and Reynolds (2013), who examine the effects of housing wealth on whether or not their child attends college and whether they attend the flagship university in their state-of-residence. We extend this analysis to examine how both housing wealth and parental income affect not just the attendance decision but also whether parents help pay for their child to go to college. This extension provides an explicit analysis of the link between parental resources and the educational decisions of children that is implied by earlier work. And, we also extend the previous literature by analyzing the effect of both parental wealth and income on college attendance and financing decisions which we show to be important.

Second, we examine the effect of parental housing wealth and income on the likelihood that children graduate from college and the cost or quality of the college children attend. It is welldocumented that while college attendance has increased in the U.S., graduation rates have not (Bound, Lovenheim and Turner, 2010; Bound and Turner, 2011). And graduation rates are quite low; among individuals who began seeking a bachelor's degree at a 4-year institution in the U.S. in the fall of 2009, only $59 \%$ completed that degree within 6 years (McFarland et al., 2017). Thus, it is important to assess whether higher levels of parental wealth and income not only increase the likelihood that children attend college but also graduate from college. ${ }^{5}$ In addition, there is a sizable literature on differential returns aross the type of college students attend, including 4-year versus 2-year institutions (Kane and Rouse, 1995), public versus private colleges (Scott, Bailey and Kienzl, 2006) and, more generally across measures of college quality including the selectivity of admissions and quality of faculty (Black and Smith, 2004, 2006; Black, Smith and Daniel, 2005; Dillon and Smith, 2017a). Accordingly, we examine whether parental wealth and income improves the "quality" of college that children attend.

Third, we consider the consequences of the parental financing decision for the subsequent debt of parents and children. As noted above, a great deal of attention has been paid to the rising levels of student loan debt and its subsequent consequences in young adulthood, irrespective of whether students complete a degree. But parents, too, take on debt to help finance their

\footnotetext{
${ }^{5}$ We note that previous work using the PSID by Cooper and Luengo-Prado (2015) find that increases in parental housing wealth increase the income of children as adults, has not found any effects of parental wealth on college completion.
} 
child's college education ${ }^{6}$ - often in the form of home equity loans using their housing wealth as collateral - and their debt also is likely to persist well after the child has completed college. While taking on debt to finance a college education may be an efficient way of financing college costs in the presence of well-functioning capital markets, it does expose borrowers to the repayment risks arising from uncertain future income streams and/or unanticipated fluctuations in the value of their collateral. In examining how parental decisions to help finance their children's college education affects their and their children's later indebtedness, we ask whether parental financial support for college reduces students' debt even as it increases their own.

To address these three issues, we use data from the 2013 Panel Study of Income Dynamics (PSID) and the Roster and Transfers Module which obtained information from all parents in the PSID on the financial help (transfers) they provided to each of their adult children for education and on the educational attainment of each adult child (Schoeni et al., 2015). We also exploit the data collected in the PSID on family wealth and debt, especially with respect to the value of the family's home and what they owe in debt on mortgages, and the debt of their children, especially in the form of student loan debt.

A key issue is the extent to which parental resources, either in the form of income or housing wealth, have a causal impact on college attendance and financing decisions, or on the subsequent financial situations of parents and their children. For example, an association between parental housing wealth and children's college attendance and financing may simply reflect sorting across families with respect to unobserved parental preferences for higher education and their own earnings capacity as well as the earlier investments in and unobserved traits (e.g., abilities) of children. To address this issue, we construct measures of changes in local housing and labor market conditions to use as instruments for parental housing wealth and income at various points in their life cycles, as well as the income of their children in early adulthood. This strategy extends previous work (Lovenheim, 2011; Lovenheim and Reynolds, 2013; Cooper and Luengo-Prado, 2015) which uses data on local housing conditions to measure the effects of housing wealth on college attendance decisions. ${ }^{7}$ The detailed geographic information included

\footnotetext{
${ }^{6}$ Based on the 2017 survey cited in footnote 1, $27 \%$ of students' college costs were financed by loans, with $30 \%$ taken by parents and $70 \%$ by the student.

${ }^{7}$ Our approach is also in the spirit of the literature on the effects of changes in wealth and income on household consumption. See, for example, Paiella and Pistaferri (2017), Browning, Gørtz and Leth-Petersen (2013), and
} 
in the PSID makes it possible to incorporate data on local labor and housing markets to identify plausibly exogenous changes in parental resources and examine the effect of these changes in parental income and wealth on transfers parents make to fund their children's college education. At the same time, we note that obtaining causal effects of whether or not parents finance their children's college education on the subsequent indebtedness of both parents and children is more challenging, even with the instrumenting strategy described above. As a result, we view the findings we present below as suggestive - rather than definitive - of the causal links between parental financing decisions and subsequent indebtedness.

We find that increases in parents' income and wealth increase the likelihood of children attending college through the mechanism of parental transfers. But, increases in parental income have a larger effect on college attendance than increases in parental wealth. In contrast, increases in parental wealth increase the likelihood that children graduate from college but we find no effect of increases in parental income on college graduation. We find evidence that the importance of parental wealth on college graduation is explained by parent's obtaining home equity loans when their child starts college. We find that neither parental income or wealth affects indicators of the type (e.g., 4-year vs. 2-year or private vs. public) or the quality of colleges children attend though sample sizes are reduced in these specifications due to data availability. Finally, we find suggestive evidence that parental financing of college increases parents' subsequent indebtedness and but little evidence that it reduces their children's student debt.

The remainder of the paper is organized as follows. In Section 2 we describe the PSID data and the samples and measures we use in our analyses. In Section 3, we consider the effect of parental income and wealth in children's college attendance and parental financing decisions. In Section 4, we examine how parental income and wealth affects the likelihood of their child graduating from college and the quality and type of school the child attends. Finally, in Section 5, we consider the correlation between children's college attendance and parental financing

Carroll, Otsuka and Slacalek (2011) for analyses of the effects of changes in housing wealth on consumption. Though we do not use changes in housing wealth and income as explanatory variables, we do use changes in wealth and income from sources that are less likely to be endogenously determined as a way to identify the effects of housing wealth and income on college attendance and financing decisions. Unlike the literature on the effects of changes in wealth and income on consumption, which pays particular attention to distinguishing between permanent and transitory changes in wealth and income, we do not attempt to explicitly disentangle these effects in our analysis. 
decisions and the subsequent indebtedness of parents and their children. We offer concluding comments in Section 6.

\section{The PSID Data}

The PSID began with a sample of roughly 18,000 people in approximately 5,000 household units in 1968. All individuals in households recruited into the PSID in 1968 are said to have the PSID gene. Individuals who are born to or adopted by someone with the PSID gene acquire the gene themselves and are recruited to become members of the PSID sample for the rest of their lives. This genealogical design implies that the study provides data on a sample of extended families at each wave. The extended family in the PSID is incomplete because some children (particularly stepchildren and children who have left the PSID sample), and some parents (for example in-laws without the PSID gene) are not included in the sample. The 2013 Roster and Transfers Module was designed to complete the parent-adult child information in the PSID and to describe the transfers that parents and adult children make to one another.

\subsection{The 2013 PSID Roster and Transfers Module}

We use the Roster and Transfers Module of the 2013 PSID in which respondents (PSID

heads and spouses) are asked to list and describe their adult children and stepchildren age 18 and older, as well as their parents, stepparents, and in-laws (including in-laws from long-term cohabiting relationships) and to report about financial and time transfer to and from their parents and adults children. Importantly for our purposes, parents report about the age and educational attainment of their adult children and about financial transfers for school they have given to each of their children since the age of 18. Both whether assistance was provided and the amount of assistance is included in the module. Respondents report about relationships and transfers with coresident and non-coresident children (see Schoeni et al. (2015) for a more complete description of the module). 


\section{$2.2 \quad$ Samples}

Our sample starts with the parents and adult children reported in the 2013 Roster and Transfers Module. We are interested in two points in the lives of these adult children: the year in which the child turns 18 when decisions about college are made, and the year in which the child turns 24 when some of the consequences of financing college can be observed.

To create our main sample, we find the year in which the child turned 18 using the birth year in the Childbirth and Adoption History augmented by age reported in the Roster and Transfers Module. Using the Parent ID file augmented with the relationship information in the Roster and Transfers Module, we link each child with his or her father and mother. Because we need to determine the parents' housing wealth and household income at this point in the child's life, we restrict our sample of parent-child pairs to those in which the parents were present as a head or wife of the PSID in the year this child was age $18 .{ }^{8}$ We also require that the year in which the child turned 18 is after 1997 (which corresponds to children in birth cohorts beginning in 1979) since some of the data elements we need in our analyses are only available starting in $1997 .{ }^{9}$ We further restrict our sample to those parents who were homeowners when the child was age 18, because of our focus on the effects of parental housing wealth on children's college attendance and financing decisions. ${ }^{10}$ Finally, following Lovenheim (2011) we trim the top $1 \%$ of changes in house prices prior to the child turning 18 which removes 14 parent-child pairs. After all of these sample selections, we have a sample of $N=2,868$ parent-child pairs with which to estimate the effect of parental wealth on college attendance and parental transfers for college.

To examine the consequences of college attendance and financing decisions on educational and financial outcomes, we examine the parent-child pairs in our main sample in the year in which the child turns 24 . This limits the sample to parent-child pairs in which the child turned

\footnotetext{
${ }^{8}$ If the parents are not a PSID head or wife in the year in which the child turns 18 we go back one year at a time until the child age 13 at which point we drop the child-parent pair.

${ }^{9}$ The housing price measure from Zillow which we used to construct a measure for changes to local housing markets had inadequate geographic coverage prior to this period.

${ }^{10}$ This restriction reduces our sample by approximately $35 \%$. While not included in the paper, we estimated versions of the empirical models described below that included parents who were not homeowners at the time their child(ren) were age 18, adjusting for the fact that we could not estimate the effects of their home equity but could estimate the effects of their income on the college and financing decisions for their children. The resulting estimates of the effects of parental income on these decisions when one included non-homeowning parents were similar to those we present below based on homeowning parents.
} 
18 prior to $2009 .{ }^{11}$ For the outcome of parental debt, this restriction yields a sample size of 2,580 for housing debt and 2,571 for non-housing debt that includes credit card debt, and auto loan debt. For the outcome of college completion, we further limit the sample to children who attended college which yields a sample size of 1,418 parent-child pairs.

Measures of college quality and child indebtedness are only available for two subsamples of children: (a) those who are a PSID head or wife by age 24 or (b) those who are members of their parents' household at age 24 but are interviewed as part of the Transition to Adulthood (TA) study. The TA study has followed children in the PSID's Child Development Study (CDS) as they become adults. The TA study includes questions about which college children attended as well as information on income and debt. Using these two sources of data, we construct a total sample of 1,756 adult children with which to analyze their non-housing debt at age 24 and 1,196 with which to analyze student loan debt at that age. We have a smaller sample of children to analyze student debt at age 24 because the PSID only started asking about this source of debt separately in 2011. For the outcomes of college cost and quality, we further limit the sample to children who attended college and whose college can be linked to the data from the National Center for Education Statistics (NCES) Integrated Postsecondary Education Data System (IPEDS) database which yields a sample size of 856 for tuition and 854 for four-year degree status. Public/private status of the college and our measure of college quality which we construct from the IPEDS data are only available for children who attend a four-year college which limits our sample to 704 for public/private college status, and 705 for college quality.

Table 1 provides a summary of the sizes of these various samples that we use in our analysis below. In Appendix A, we also present descriptive statistics of the demographic characteristics of the parents and children, measured at the time the children were age 18, of the sample of the 2,866 parent-child pairs used in our analysis of college education decisions.

\footnotetext{
${ }^{11}$ If the relevant data are not available for the child or parent in the year in which the child is age 24 we go back one year at a time until the child is age 22 and forward one year at a time until the child is 27 .
} 


\section{$2.3 \quad$ Measures}

Below we describe how we construct the various measures used in our analyses. In later sections, we provide summary statistics.

College Attendance and Graduation: We measure college attendance and college graduation using the Roster and Transfers data. We consider a child to have attended college if the parents report in the Roster and Transfers data that the child has attended some college or has a college degree. This measure is somewhat different from the previous literature (Lovenheim, 2011; Lovenheim and Reynolds, 2013; Cooper and Luengo-Prado, 2015) which uses the annual PSID data to determine enrollment. The benefit of the measure from the Roster and Transfers data is that is considerably easier to identify students who enroll in but do not complete college. This is important to understanding the potential difference in effects of attending vs. graduating from college. We measure college graduation by a parental report that the child's highest level of educational attainment is college graduate or more.

Financial Transfers for College: Parents are considered to have given a financial transfer to a child for educational expenses if they report having done so in the long-term transfers question in the Roster and Transfers Module. We eliminate the small number of cases in which parents report that their child has educational attainment below "some college" and report having given a transfer for post-secondary educational expenses. We measure the amount that parents report giving to their child in $2013 \$ .^{12}$

College Cost and Quality: We link responses from the main PSID interview or the TA study on the college attended to measures of college cost and quality available from the National Center for Education Statistics (NCES) Integrated Postsecondary Education Data System (IPEDS) database. We obtain the annual tuition costs for a full-time student at that institution in the

\footnotetext{
${ }^{12}$ We note that the decision to measure the amount of transfers in $2013 \$$ is not straightforward. Though parents were asked the question on amounts of transfers in 2013, it is not clear whether the reported amounts in terms of current dollars or the dollar value(s) at the time the transfers were made. We have re-run our specifications of regressions for the effects of parental housing wealth and income on the amount of transfers given to support a child's college education under either of these two assumptions about parental reporting. While the magnitudes of the corresponding coefficients differed, none of the inferences we make below were affected. Accordingly, we only present results under the assumption that parents reported the amounts of these transfers in current (2013) dollars.
} 
year they would have started college. In doing so we use the state of residence of the parent at that time to determine whether children would have paid in-state or out-of-state tuition at any public institutions. ${ }^{13}$ For college quality we use three separate measures. First, we measure whether the institution grants 4-year degrees. Second, we use whether a child attended a private university, where we restrict our attention to students who attend a 4-year university. Finally, we use the college quality index used in Black and Smith (2004), Black, Smith and Daniel (2005), Black and Smith (2006), Dillon and Smith (2017a), and Dillon and Smith (2017b). ${ }^{14}$ The index is based on the following measures of colleges' selectivity and resources: college's mean SAT or ACT scores; percent of applications rejected; average salary of faculty involved in instruction; and the undergraduate faculty-student ratio. ${ }^{15}$ The index is the first principal component of these four indicators of college quality measured in $2008 .^{16}$

Parental Housing Wealth and Income: Over the entire span of the PSID, heads of households or their proxy are asked whether they are a homeowner and, if they are, to provide an estimate of the value of their home and the remaining balance, if any, on their home mortgages and/or home equity loans. Mortgage debt includes all primary and secondary mortgages, along with home equity loans and lines of credit on the individual's primary residence. Then, we define an estimate of the parents net home equity as the reported market value of their home less any remaining mortgage balances. Parental income is measured by total family income reported in the annual PSID family data.

Parental and Child Indebtedness: We consider several forms of indebtedness for both parents and their children. For parents, we consider mortgage debt, the sum of all their primary and secondary mortgages along with home equity loans, and all other non-housing debt, including outstanding credit card and medical debt, as well as other outstanding loans. These measures are obtained in the PSID wealth module which has been included in every survey since 1997. For children, we examine debt in the form of outstanding student loans, as well as total other

\footnotetext{
${ }^{13}$ We use in-state tuition if the parents resided in the same state as the institution in the year the child turned 18, and out-of-state tuition otherwise.

${ }^{14}$ We thank Nora Dillon and Jeff Smith for providing us with the latest version of these quality indices for 4-year and 2-year colleges in the U.S.

${ }^{15}$ These dimensions of quality for colleges in the U.S. are obtained from the Integrated Post-Secondary Education Data System (IPEDS) and college rankings by U.S. News $\mathcal{E}$ World Report.

${ }^{16}$ The particular version of college quality index we use takes on values from -9 to +9 and is constructed to have a mean of 0 across all of 4-year colleges and universities in the U.S.
} 
non-housing debt. Student loan debt is obtained from the TA survey and from the PSID wealth module after 2011. Total non-housing debt is measured in the TA survey and in the PSID wealth module.

\section{Effects of Parental Wealth \& Income on Children's College Attendance and Its Financing}

In this section we examine children's college attendance decisions and parents' role in helping to finance their children's choices. In particular, we are interested in how changes in parents' wealth and income affect these choices. We begin by defining the notation for college attendance and parental financing thereof as well as parental income and housing wealth and discussing the empirical distributions of parental wealth and income across college attendance and financing decisions in our sample. We then describe our econometric strategy for estimating the causal impact of parental wealth and income on the decision of children to attend college and the decision of parents to help pay for it and discuss our empirical findings.

\subsection{Modeling Children's College and Parental Financing Choices}

We define the following variables to characterize the college attendance and parental financing decisions for the $j^{\text {th }}$ child of the $i^{\text {th }}$ parent when the child is age 18 :

$$
\begin{aligned}
& \text { EduFin } 0_{i j, 18_{j}}= \begin{cases}1, & \text { if child } j \text { of parent } i \text { did not enroll in college, } \\
0, & \text { otherwise. }\end{cases} \\
& \text { EduFin } 1_{i j, 18_{j}}= \begin{cases}1, & \text { if child } j \text { of parent } i \text { enrolled in college \& parents didn't help pay, } \\
0, & \text { otherwise. }\end{cases}
\end{aligned}
$$


and

$$
\text { EduFin } 2_{i j, 18_{j}}= \begin{cases}1, & \text { if child } j \text { of parent } i \text { enrolled in college \& parents did help pay, } \\ 0, & \text { otherwise. }\end{cases}
$$

where $\operatorname{EduFin} 0_{i j, 18_{j}}+\operatorname{EduFin} 1_{i j, 18_{j}}+\operatorname{EduFin} 2_{i j, 18_{j}}=1$.

Conditional on EduFin $2_{i j, 18_{j}}=1$, we can measure the amount of financial help parent $i$ provided to child $j$ in support of the child's college attendance. Denote this amount as CollTrans $_{i j, 18_{j}}$.

Table 2 shows the distribution of EduFin. In our sample, $44 \%$ of children do not enroll in college, $30 \%$ enroll but do not receive financial help from parents and $26 \%$ enroll in college with a transfer from a parent. The mean amount of the transfer is $\$ 7,800$.

As noted above, we focus on how parental housing wealth and parental income influence these decisions. To begin, we characterize the housing measures we construct from the PSID data. Let $M k t$ Value $_{i m t_{18, j}}$ denote the parents' estimated market value of their home (measured in 2013 dollars) located in market $m$ (which is in state $s$ ) in the year in which child $j$ was age 18 $\left(t_{18_{j}}\right)$. Further, let Mort Bal $_{i m t_{18_{j}}}$ denote the remaining balances on parents' home mortgages and home equity loans as of year $t_{18_{j}}$, again in $2013 \$$. Then, we define an estimate of the parents (net) home equity as:

$$
H_{\text {imt }_{18_{j}}}=\text { MktValue }_{\text {imt }_{18_{j}}}-\text { MortBal }_{i m t_{18_{j}}} .
$$

Let $Y_{i m t_{18_{j}}}$ denote the parent $i$ 's total household income in year $t_{18_{j}}$ when they were residing in local labor market $m$.

In Table 3 we display how parental housing wealth, $H_{i m t_{18_{j}}}$, and annual income, $Y_{i m t_{18_{j}}}$, differ by college attendance and parental financing decisions. The patterns of parental net equity and income across college attendance and financing decisions are predictable. The parents of children 
who attend college without financial support have $\$ 21,200[=\$ 50,200-\$ 29,000]$ more in net home equity and $\$ 22,300[=\$ 75,100-\$ 52,800]$ more in income when their child is age 18 compared to the parents of children who do not attend college. The parents of children who attend college with financial support have $\$ 63,400$ more in net home equity and $\$ 45,200$ more in income than those whose children attend college without parental financial help.

To model parental-child college and financing decisions, let the utility/payoff for $E d u F i n k_{i j, 18_{j}}$ be denoted by $U_{k i j m, 18_{j}}^{*}$ and assume that choice $k=0$ is the base category. The payoff functions for parent $i$ of child $j$ made when the child is age 18 are given by:

$$
U_{k i j m, 18_{j}}=\lambda_{k 0}^{U}+\lambda_{k 1}^{U} H_{i m t_{18_{j}}}+\lambda_{k 2}^{U} Y_{i m t_{18_{j}}}+\boldsymbol{\lambda}_{k 3}^{U} \boldsymbol{X}_{i j}+\boldsymbol{\lambda}_{k 4}^{U} \boldsymbol{M}_{m t_{18_{j}}}+\phi_{k t_{18_{j}}}^{U}+\delta_{k s}^{U}+\varepsilon_{k i j m, 18_{j}}^{U},
$$

for $k=0,1,2$, where the $H_{i m t_{18_{j}}}$ and $Y_{i m t_{18_{j}}}$ are defined above, $\boldsymbol{X}_{i j}$ is a vector of demographic characteristics of parents $i$ and their $j^{\text {th }}$ child, $\boldsymbol{M}_{m t_{18_{j}}}$ is a vector of time-varying characteristics of location $m$ in year $t_{18_{j}}, \phi_{t_{18_{j}}}$ and $\delta_{s}$ are year and state-of-residence fixed effects, respectively, and $\varepsilon_{k i j m, 18_{t}}$ are choice-specific unobserved parent and child traits.

We include in $\boldsymbol{X}_{i j}$ a set of demographic characteristics including the age, marital status, race, and education of the parent. Also included are a set of variables describing the family structure of the child's household at age 18 including whether the household is headed by a single-female, the number of children in the household under age 16, whether there is a child in the household who is less than five years older than child $j$, whether there is a child in the household who is less than five years younger than child $j$, and the gender of child $j$. (See Appendix A for the list of these variables and their sample means.)

We include in $\boldsymbol{M}_{m t_{18_{j}}}$ the average weekly wage and employment rate in market $m$ in year $t_{18_{j}}$, where the latter variables are taken from the Quarterly Census of Employment and Wages (QCEW). We use a share-weighting approach to make the average weekly wage more accurately reflect the labor market teenage workers would face if they do not attend college. We use the Current Population Survey to calculate the composition of industries that teenagers are employed in nationally in each year and apply these weights to local industry-specific wages. We also control for the college-wage premium for younger workers directly. Following Lovenheim 
and Reynolds (2013) we use data from the Current Population Survey to calculate the collegewage premium for young workers in the state, $s$, in which market $m$ is located in year $t_{18_{j}}$ as the ratio of hourly wages of 25 - 40 year olds with a bachelor's degree (BA) to the hourly wages of 25 - 40 year olds whose highest level of educational attainment is a high school diploma. We also include the college - associate degree wage premium calculated as above but using individuals with an associate's degree as the comparison group. As long as high-skilled labor demand is not highly localized, these state-level measures control for the demand for high-skilled vs. low-skilled labor for younger workers.

We characterize the optimal college/financing choice for child $j, k^{\dagger}$, as follows:

$$
k_{i}^{\dagger}=\arg \max _{k} U_{k i j m, 18_{j}}, k=0,1,2 .
$$

Assuming that the random variable, $\varepsilon_{k i j m, 18_{j}}^{U}$, has a Type II extreme value distribution and assuming that we treat $H_{i m t_{18_{j}}}$ and $Y_{i m t_{18_{j}}}$ as exogenous to child $j$ 's college enrollment and parental financing decisions, it follows that the model of the college attendance and its financing choice can be estimated as a multinomial logit model.

As noted in the Introduction, the assumption that $H_{i m t_{18_{j}}}$ and $Y_{i m t_{18_{j}}}$ are exogenous is a strong one. Accordingly, we wish to allow for the potential endogeneity of these two variables in the estimation of the payoff functions in (5). To deal with the endogeneity of $H_{i m t_{18_{j}}}$ and $Y_{i m t_{18_{j}}}$, we use a control function estimator (Blundell and Powell, 2003) applied to the multinomial logit specification (Petrin and Train, 2010; Wooldridge, 2014). This estimator can be implemented in two stages. In the first stage, we regress the endogenous variables $H_{i m t_{18_{j}}}$ and $Y_{i m t_{18_{j}}}$ on exogenous regressors, including the exogenous variables, $\boldsymbol{X}_{i j}$ and $\boldsymbol{M}_{m t_{18_{j}}}$ in (5) and year and state-of-residence fixed effects, as well as a vector of instrumental variables, $\boldsymbol{Z}_{i m t_{18_{j}}}$ (which we define in the next section) to account for the endogeneity of $H_{i m t_{18_{j}}}$ and $Y_{i m t_{18_{j}}}$. That is, these first-stage regressions are:

$$
\begin{aligned}
H_{i m t_{18_{j}}} & =\boldsymbol{\pi}_{1}^{H} \boldsymbol{Z}_{i m t_{18_{j}}}+\boldsymbol{\pi}_{2}^{H} \boldsymbol{X}_{i j}+\boldsymbol{\pi}_{3}^{H} \boldsymbol{M}_{m t_{18_{j}}}+\phi_{t_{18_{j}}}^{H}+\delta_{s}^{H}+\nu_{i m t_{18_{j}}}^{H}, \\
Y_{i m t_{18_{j}}} & =\boldsymbol{\pi}_{1}^{Y} \boldsymbol{Z}_{i m t_{18_{j}}}+\boldsymbol{\pi}_{2}^{Y} \boldsymbol{X}_{i j}+\boldsymbol{\pi}_{3}^{Y} \boldsymbol{M}_{m t_{18_{j}}}+\phi_{t_{18_{j}}}^{Y}+\delta_{s}^{Y}+\nu_{i m t_{18_{j}}}^{Y}
\end{aligned}
$$


One then retrieves the residuals from these regressions, which we denote as $\widehat{\nu}_{i m t_{18_{j}}}^{H}$ and $\widehat{\nu}_{i m t_{18_{j}}}^{Y}$, respectively. In the second stage, we estimate a multinomial logit model where we include $\widehat{\nu}_{i m t_{18_{j}}}^{H}$ and $\widehat{\nu}_{i m t_{18_{j}}}^{Y}$ as additional regressors, with separate coefficients, in the payoff functions in (5). To account for the estimation error in $\widehat{\nu}_{i j m t_{18_{j}}}^{H}$ and $\widehat{\nu}_{i j m t_{18_{j}}}^{Y}$ and the quasi-ML nature of estimation in the second stage, we adjust the estimation of the variance-covariance matrix of the $\lambda \mathrm{s}$ as characterized in Wooldridge (2014). We use bootstrap to calculate these standard errors.

Finally, conditional on EduFin2 = 1, we can estimate the impacts of parental housing wealth and household income on the amount of the parents' transfer, CollTrans ${ }_{i m t_{18}}$. Mimicking the specification of payoffs in (5), we estimate the following OLS regression:

$$
\text { CollTrans }_{i m t_{18_{j}}}=\lambda_{0}^{T}+\lambda_{1}^{T} H_{i m t_{18_{j}}}+\lambda_{2}^{T} Y_{i m t_{18_{j}}}+\boldsymbol{\lambda}_{3}^{T} \boldsymbol{X}_{i j}+\boldsymbol{\lambda}_{4}^{T} \boldsymbol{M}_{m t_{18_{j}}}+\phi_{t_{18_{j}}}^{T}+\delta_{m}^{T}+\varepsilon_{i m t_{18_{j}}}^{T}
$$

where all of the control variables are the same as described above but we use MSA level fixed effects for urban residents and state level fixed effects for rural residents instead of state-level fixed effects. To account for the potential endogeneity of $H_{i m t_{18_{j}}}$ and $Y_{i m t_{18_{j}}}$ in (9), we employ an instrumental variables estimator (2SLS), using the same vector of instruments, $\boldsymbol{Z}_{i m t_{18_{j}}}$, used in the control function estimator of the parameters in the payoff functions in (5) which we describe next.

\subsection{Instrumental Variables: Changes in Local Housing Prices \& Wa- ges}

As noted above, we seek to instrument for parent's housing wealth, $H_{i m t_{18_{j}}}$, and income, $Y_{i m t_{18_{j}}}$, in the estimation of the payoff functions for the college education and financing choices parents make for their $j$ th child. In this section, we describe the variables we use as instruments $(Z)$ in our analyses and how they are constructed.

We use changes in local housing market prices and changes in labor market wages as our instruments. In particular, we construct measures of the change in the parents' housing wealth and parental income immediately before child $j$ reaches age 18 to serve as instrumental variables for parental housing wealth and income in the estimation of our college attendance and financing 
models and our estimation of the effects of these decisions on subsequent educational outcomes described in Section 4. In spirit of the approach in Lovenheim and Reynolds (2013), we use changes in market-level measures of average housing values in the local market in which parents resided in the year in which the child was age 16, i.e., in year $t_{16_{j}}$. We use lagged values of changes in local market conditions for two reasons.

First, we want to to avoid the possible endogenous decision that parents may make to move to a different locality (market) at the time of their child's college decision, possibly to improve either their ability to finance the costs of college, e.g., they sell a more expensive home, take the equity from that home to pay for college and move to a less expensive home, or to reduce the cost of the college their child may attend, e.g., moving closer to a college or to a state that charges lower tuition.

Second, one might expect that parents base their assessment of whether they can use the equity in their home as collateral for a loan to pay for their children's college education (via a home equity loan, for example) based on any changes in local housing values one or two years prior to the actual decision, rather than based on what happens to housing values in the year when their child would be going to college. We note that this strategy of using changes in local housing values a few years prior to the child's college decision is similar to the one used by Lovenheim (2011) and Lovenheim and Reynolds (2013) in their studies of the effects of parental housing wealth on children's decisions to attend college. Finally, we note that we use the same strategy when constructing measures of the changes in local labor market conditions that may be expected to affect their personal income.

More precisely, our instrument for changes in local housing values is constructed as follows. For the locality, $m$, in which parents reside in year $t_{16, j}$, we obtain housing price indices, $H P I_{m t}$, from external data sources to construct the percentage change in local housing values. Where possible, i.e., where we have data on local housing prices, we define the local housing market at the zip code level and, where possible, we use housing price indices constructed by Zillow. For zip codes where a Zillow price index is not available in year $t_{16, j}$, we use the Zillow index for the county in which the parents/child reside in that year. When a price index is not available for the parents' county of residence, we use the price index of the MSA- or state-of-residence. Finally, 
for some years and locations in which the parents in our data reside in markets not covered by Zillow data, we make use of the housing price index constructed by the Federal Housing Finance Agency (FHFA) as our measure of $H P I_{m t}$. With the resulting indices, we construct the percentage change in this index over a 4-year period centered on year $t_{16_{j}}$,

$$
\frac{H P I_{m t_{18_{j}}}-H P I_{m t_{14_{j}}}}{H P I_{m t_{14_{j}}}} .
$$

We note that by using percentage changes in housing price indices, $H P I_{m t}$, rather than simple changes, we minimize any problems of non-comparability of the Zillow and FHFA housing price indices. ${ }^{17}$ We then "scale" this percentage change by the net home equity the parents report in year $t_{16_{t}}$ to form our housing market instrument:

$$
\Delta H P I_{m t_{18_{j}}} \equiv H_{i m t_{16_{j}}}\left[\frac{H P I_{m t_{18_{j}}}-H P I_{m t_{14_{j}}}}{H P I_{m t_{14_{j}}}}\right]
$$

We note that we found that trimming the changes affects the precision of our results.

For our instrumental variable for local labor market conditions, we use data from the QCEW to obtain the average annual wages in each county, $m$, in each year, $t$. We then construct average wages by county-of-residence of parents for the years around when their child was age 16, i.e., $t_{16_{j}}$. We denote these average wage measures by $\bar{W}_{m t}^{P}$. We then construct the percentage changes in these average wages, i.e.,

$$
\frac{\bar{W}_{m t_{18_{j}}}^{P}-\bar{W}_{m t_{14_{j}}}^{P}}{\bar{W}_{m t_{14_{j}}}^{P}}
$$

and scale it by parent's annual income in year $t_{16, j}$ to construct the following instrumental variable:

$$
\Delta W_{m t_{18_{j}}}^{P} \equiv Y_{i m t_{11_{j}}}\left[\frac{\bar{W}_{m t_{18_{j}}}^{P}-\bar{W}_{m t_{14_{j}}}^{P}}{\bar{W}_{m, t_{14_{j}}}^{P}}\right] .
$$

Thus, our vector of instruments is given by $\boldsymbol{Z}_{i m t_{18_{j}}} \equiv\left(\Delta H P I_{m t_{18_{j}}}, \Delta W_{m t_{18_{j}}}^{P}\right)$. The statistics for

\footnotetext{
${ }^{17}$ We trimmed these changes when they were exceedingly large in absolute value.
} 
tests of the joint significance of the instruments for both parental net equity and income are in Appendix Table B.1.) and indicate sufficiently strong instruments.

\subsection{Empirical Results}

Table 4 presents the results of estimating (5) and (9). For the college choice and financing models, (5), we show estimates of the marginal effects of parental net equity $(H)$ and income $(Y)$ on children's college choices (EduFin0, EduFin1 and EduFin1) for the unadjusted multinomial logit specification as well as those for our preferred estimates based on the control function estimator. For the models of amounts conditional on a transfer, (9), we present OLS and 2SLS coefficient estimates for $H$ and $Y$.

In Panel $\mathrm{A}$ of Table 4, we present estimates of the marginal effects of parents net (home) equity when their child was age $18\left(H_{i m t_{18_{j}}}\right)$ and parents' annual income at that age $\left(Y_{i m t_{18_{j}}}\right)$ for the unadjusted multinomial logit specification. A $\$ 10,000$ increase in home equity decreases the likelihood that the child does not attend college by 0.39 percentage points, increases the likelihood that they attend college but with no parental transfer by 0.03 percentage points and increases the likelihood that they go to college and their parents provide financial help by 0.36 percentage points, with the first and the last of these effects being statistically significant at least the $10 \%$ level. Similarly, a $\$ 10,000$ increase in parents' annual income decreases the likelihood that the child does not attend college by 1.96 percentage points, increases the likelihood that they attend college but with no parental transfer by 0.85 percentage points and increases the likelihood of the child going college and receiving financial help from their parents by 1.11 percentage points, with all three of these effects being being statistically significant at the $1 \%$ level.

In Panel B of Table 4 we account for the potential endogeneity of parental home equity and income on these choices. We find that a $\$ 10,000$ increase in parental housing wealth increases the likelihood of attending college with a parental transfer by 0.58 percentage points. The effect of a $\$ 10,000$ increase in income is over twice as large, increasing the likelihood of attending college with a parental transfer by 1.69 percentage points and decreasing the likelihood of not attending college by 2.14 percentage points, with both of these effects being precisely estimated. 
In order to compare the effects of parents' net home equity and income on comparable terms, we compute estimates of the elasticities for these variables. For our preferred control function estimates, the elasticity of parental income with respect to not going to college is -0.374 and for going to college and receiving financial help is 0.500. In contrast, for parents' net housing equity the elasticities are much smaller at (-0.046 and 0.128 , respectively). ${ }^{18}$

Our estimates of the effects of parental housing wealth $(H)$ on the likelihood of a child attending college - here measured as the negative value of the estimates of $H$ on not attending college - are consistent with and quite similar in magnitude to those in Lovenheim (2011), although only the multinomial logit estimates are statistically significant. Furthermore, we find that increases in parental income $(Y)$ increase the likelihood of attending college - again measured as the negative of the effects on not attending college - which is consistent with the findings in Belley and Lochner (2007); Lochner and Monge-Naranjo (2011), and Lochner and Monge-Naranjo (2012). Moreover the latter effects are statistically significant for both our multinomial and control function specifications. But, as discussed above, our findings make clear that the mechanism through which parental income and wealth affect college attendance is through their effects on the the likelihood that parents choose to help finance their child's education. Furthermore, the effects of $H$ and $Y$ on the college and transfer choice (EduFin2) are statistically significant for both the multinomial logit and control function specifications, while the effects of both of these variables on the college but no parental transfer small and not statistically significant for our preferred control function specification.

The estimated effects of parental home equity and parental income on the amount of parental transfers for their children's college education, for both OLS and 2SLS, are found in Panel C of Table 4. Ignoring the endogeneity of parental home equity and income, the OLS results indicate that a $\$ 10,000$ increase in net home equity would increase the amount of parental financial support by an average of $\$ 316$, while a comparable increase in parents' income would increase the average amount transferred by $\$ 769$. In our preferred 2SLS specification, we find that a $\$ 10,000$ increase in home equity increases parental transfers by only $\$ 205$ and this effect is no longer statistically significant. However, we find that increases in parental income now have

\footnotetext{
${ }^{18}$ These elasticities are evaluated at the means of both the probabilities of EduFin 0 and EduFin 2 and $Y_{i m t_{18_{j}}}$ and $H_{i m t_{18_{j}}}$ found in Table 2 .
} 
a much larger effect on the amount of parental transfers, with a $\$ 10,000$ increase in parental income resulting in an average increase in parental transfers $\$ 1,510$, with the latter effect being precisely estimated. Translating these effects of parental home equity and income on parental financial support for their children going to college to elasticities, we again find that the elasticity for net home equity is fairly small (0.151) while the elasticity with respect to parental income is sizable (1.489).

Taken together these results strongly suggest that both parental wealth and parental income are important in determining both the likelihood of their children attending college and, importantly, their parents helping to finance it. But, that the effects of changes in parental income on college attendance and financing decisions are larger than similar changes in parental wealth. One important difference between our work and prior work on the role of housing wealth in college attendance decisions is the time period that we analyze. Lovenheim (2011) focused on the years between 2000 and 2005 when house prices were growing rapidly and home equity lines of credit were plentiful. In contrast, we include both an earlier period (1997 - 1999), and, more importantly, the later period (2006 - 2013) in which house prices fell or were largely stagnant

and home equity lines of credit became increasingly difficult to obtain. Changes in the ability to access home equity lines of credit have played a role in explaining the relative importance of income in college attendance and financing decisions. When home equity lines of credit become more difficult to access, parental income may have become a more likely source for financing large consumption expenses like their children's college educations. It is also possible that family income became more important in the ability to access credit in the aftermath of the Great Recession which would exacerbate the importance of income for being able to provide financial assistance for college. We return to this issue below in the discussion of our results for college graduation.

\section{Effects of Parental Wealth \& Income on College Gra- duation and Costs \& Quality of Colleges Attended}

In the preceding section, we found that parental income, more so than parental home equity, increases the likelihood that children attend college and that this effect is largely driven by 
the fact that parental income increases the likelihood and the amount of financial help parents provide for sending their children to college. We next examine whether parental wealth and income affect the likelihood that children graduate from college and the quality of the college they attend.

\subsection{Modeling Children's College Attainment \& Quality}

As noted in Section 2.3, we use information on completed schooling reported in the 2013 PSID Roster and Transfers Module to form measures of whether each child $j$ of parent $i$ that attended college at age 18 graduated from college - which we denote by dummy variable Grad $_{i j, 18_{j}}$. We obtain the annual tuition costs for a full-time student at that institution in the year they would have started college — which we denote by the variable Tuition $_{i j, 18_{j}}$. We measure whether the institution was a 4-year college or university - denoted by the variable $4 Y r C o l l_{i j, 18_{j}}$ - and whether it was a private institution - denoted by the dummy variable Private $_{i j, 18_{j}}$. We denote the quality index described in Section 2.3 by Quality ${ }_{i j, 18_{j}}$.

In Table 5, we display the mean values for these measures of the college attributes described above. One can see that all of the measures of college attainment and quality are greater for children attending college with parental financial support compared to those attending without it. This is especially true for the college quality index $\left(\right.$ Quality $\left._{i j, 18_{j}}\right)$, which increases from 0.07 for college attended by children who did not receive financial help from their parents to 0.49 for those that did.

We examine how parental income and parental housing wealth affect college quality using changes in parental income and wealth in the years before a child turns 18 as instruments for income and housing wealth. These specifications mirror those on college attendance and financing decisions in Section 3.3 estimating regressions of the following form:

$$
\text { CollOut }_{q i j, 18_{j}}=\lambda_{q 0}^{O}+\lambda_{q 1}^{O} H_{i m t_{18_{j}}}+\lambda_{q 2}^{O} Y_{i m t_{18_{j}}}+\boldsymbol{\lambda}_{q 3}^{O} \boldsymbol{X}_{i j_{18_{j}}}+\boldsymbol{\lambda}_{q 4}^{O} \boldsymbol{M}_{m t_{18_{j}}}+\phi_{q t_{18_{j}}}^{O}+\delta_{q m}^{O}+\varepsilon_{i j, 18_{j}}^{q},
$$

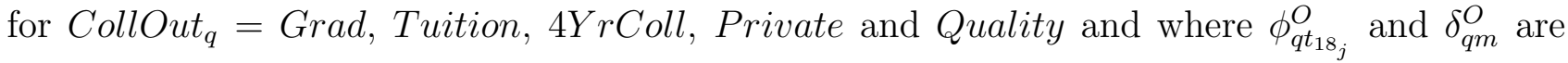
year and the parents' county fixed effects, respectively. The vector, $\boldsymbol{X}_{i j_{18_{j}}}$, used in (14) is the 
same as the one used in equations (5) and (7) through (9) except that also includes a dummy variable for whether the child has become a head or wife in a PSID household by age 24. This extra variable controls for the source of data from which college information is obtained (PSID main interview versus Transition to Adulthood). ${ }^{19}$

Finally, to account for the potential endogeneity of $H_{i m t_{18_{j}}}$ and $Y_{i m t_{18_{j}}}$ in (14), we again employ a 2SLS estimator for (14), using the two instruments, $\Delta H P I_{m t_{18_{j}}}$ and $\Delta W_{m t_{18_{j}}}^{P}$, that were defined in Section 3.2 and used in the control function estimation of college choices and parental financing decisions and the amount of parental financial support provided to their child.

\subsection{Empirical Results}

In Panel A of Table 6 we present the estimates of the effects of parental net housing equity $\left(H_{i m t_{18_{j}}}\right)$ and income $\left(Y_{i m t_{18_{j}}}\right)$ on whether child $j$ graduates from college as well as the various indicators of the quality of the college. OLS estimates are presented in in columns (1) and (3) and 2SLS estimates in columns (2) and (4) for these outcomes outcomes. We first consider the results for whether the child graduates from college, displayed in Panel A of Table 6. We find evidence that parent's net equity at the time of the college decision increases the probability that their child graduates from college. But, in contrast to our findings on college attendance, we do not find any effect of family income on college graduation once we control for the endogeneity of family income.

The results on graduation show an interesting contrast between how parental resources when a child is age 18 affect college enrollment versus college graduation. We find that both parental income and parental wealth when a child is 18 increase the likelihood of attending college but only parental wealth when a child is 18 increases the likelihood of graduating from college.

One possible explanation for these contrasting results is that increases in parental income

\footnotetext{
${ }^{19}$ As noted in Section 2.2, if adult children have become a head or wife of a PSID household by age 24, their data can be drawn from the PSID main interview and is, in principle, available for all of the years, $t_{24_{j}}$, that we analyze. In contrast, if adult child $j$ does not become a head of wife of a PSID household by 2013 - the year of the last wave of the PSID used in our analyses - we use data about the characteristics of the college child $j$ attended from the PSID Transition to Adulthood sample. But this latter sample is only available for more recent (calendar) years. Thus, including this extra dummy variable in (14) allows us to account potential differences across these two different sources of data used to determine the dependent variables, Tuition $_{i j, 18_{j}}$,

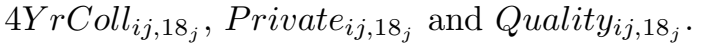


when their child is 18 can finance their child's college enrollment but may not be sufficient, on average, to cover the full costs of attaining a degree. In contrast, parents who experience an increase in housing wealth can secure loans, such as a home equity loan, which can be used to finance their child's entire college career. These loans are common, almost $12 \%$ of parents in our sample had such a loan when their child was age 18.

To explore this possibility, we examine the effect that parents having a home equity loan when their child was 18 has on the likelihood of their child graduating from college over and above parental wealth $(H)$ and income $(Y)$ (results not shown in Table 6). Adding this indicator variable to the regression in (14) for Grad as the outcome, we find that having a home equity loan at the time the child is age 18 increases the likelihood that the child graduates from college by 8.6 percentage points. ${ }^{20}$ These results suggest that home equity loans are an important channel though which parents are able to continue to provide financial support throughout their child's college years. Combined with the larger effect of parental income than parental wealth on college attendance, the results suggest that increases in family income change choices about college only at a short lag length, whereas wealth effects are more enduring.

In Panels B and C of Table 6, we present OLS and 2SLS estimates of the effects of parental net equity and income on the various attributes of the college the children attended, starting at age 18. Looking first at the effects of parental home equity on the various attributes and types of colleges attended, we find the effects to be very small. For example, a $\$ 10,000$ increase in parental net equity would result in the child going to a college that is only slightly more expensive, ranging from $\$ 99$ based on OLS estimates to $\$ 112$ based on the 2SLS estimates. (Recall from Table 5 that the average annual tuition of college attended is $\$ 9,682$.) Similarly, a $\$ 10,000$ increase in parents' home equity would increase the probability of attending a private college by 0.2 percentage points (based on OLS) and would reduce it by 0.7 percentage points (based on 2SLS). Furthermore, none of the effects of parental home equity are precisely estimated. With respect to the effects of parental income on the tuition, types and quality of the college attended,

\footnotetext{
${ }^{20}$ We also estimate a specification in which we treat having a home equity loan at age 18 as an additional endogenous variable, using a set of squared changes in local home prices and local labor markets and their interactions as additional instruments, and find that in this specification, having a home equity loan when the child is 18 also increases the likelihood of graduation. The results for this augmented specification of the likelihood of a child graduating from college are found in Table C.1.
} 
none of the other estimated effects of parental are precisely estimated, with the exception of the OLS estimated effects on the quality of college children attended. Furthermore, increases in parental income seem to have relatively negligible effects whether their children go to a more expensive school, one that is private or one that is of higher quality.

The lack of precision in the estimates of the effects of parental home equity and income may be due, in part, to the smaller sample sizes used to estimate the effects found in Table 6 compared the likelihood of graduation in Panel A of Table 6. The samples used to estimate the effects presented in Panels $\mathrm{B}$ and $\mathrm{C}$ of Table 6 are almost half of those used to estimate the effects for college graduation in Panel A. Although we note in Appendix Table B.1 that the first-stage results are slightly above the conventional cutoff value.

In summary, it appear that increases in parental wealth do result in statistically significant but small increases the likelihood that children will graduate from college. Our finding for the likelihood of graduation is notable, since Cooper and Luengo-Prado (2015) did not detect any effects of parental housing wealth on college graduation, despite the fact that parental housing wealth appears to increase the labor earnings of their adult children. One reason for the greater precision of our results is that we use the better measure of the educational attainment of children available in the 2013 Roster and Transfers data. At the same time, our findings do not clearly indicate that greater parental income (or housing wealth) decidedly alters the likelihood of their child attending a more expensive college, a private one, or a more highly ranked one, although the smaller sample sizes used to estimate these effects may have contributed to latter null findings.

\section{Consequences of Parental Financing Decisions for Pa- rents' and Child's Subsequent Indebtedness}

Finally, we provide evidence of the consequences of decisions about attending college and parental financing on levels of debt parents and children hold after the college years. In what follows we outline our strategy for estimating these relationships, explicitly examining whether children who attend college and their parents end up accumulating more debt, whether parental 
financial support for college leaves parents with more debt, and whether such support reduces the amount of debt children accumulate.

\subsection{Modeling the Effects of College/Financing Choices on Later Fi- nancial Debt of Parents and Adult Children}

Let $D e b t_{n h t_{a_{j}}}$ denote the debt of household $n$ where $n=i$ for the parent household and $n=j$ for the child household, of type $h$, measured in year $t_{a_{j}}$ when child $j$ is age $a$. We choose $a=24$ as six-years after enrollment decisions and when financing for higher education is largely complete. For parents, we consider mortgage debt $\left(\operatorname{Mort}_{\log } \mathrm{l}_{{i t_{24_{j}}}}\right)$, and all other non-housing debt $\left(O t h D e b t_{i t_{24_{j}}}\right)$, both measured when the child is age $24\left(t_{24_{j}}\right)$. For children, we examine debt in the form of outstanding student loans (StudentDebt ${ }_{j t_{24}}$ ), as well as total non-housing debt $\left(O t h D e b t_{j t_{24_{j}}}\right)$, both measured in $t_{24_{j}}$.

In Table 7 , we display the mean values of mortgage and total non-housing debt for parents and student loan and other non-housing debt for children at age 24. Parents, on average, have $\$ 69,500$ in mortgage debt and $\$ 13,400$ in other debt when their child is age 24 . Parents whose child did not attend college have much lower levels of debt: $\$ 45,400$ in mortgage debt and only $\$ 8,400$ in other debt. Parents of children who did attend college but did not provide financial help hold higher debt balances: $\$ 59,400$ in mortgage debt and $\$ 13,500$ in other debt. Finally, parents who helped finance their child's college education have much higher amounts of both types of debt: $\$ 100,100$ in outstanding mortgage debt and $\$ 18,000$ in other debt.

At age 24 , children, on average, hold $\$ 12,300$ in student debt and the same amount in total non-housing debt. Those children who did not attend college, not surprisingly, hold almost no student loan debt, $\$ 2,200$ (presumably because of other education-related expenses) and $\$ 8,000$ in total non-housing debt. Children who attended college but received no help from their parents hold only somewhat more debt than the average child, but a good deal more than their counterparts who did not attend college: $\$ 15,000$ in other debt and $\$ 16,800$ in outstanding student loans. Finally, among those children who went to college and got financial help from their parents, their debt levels were slightly, but only slightly, lower than those who went to college without parental help: $\$ 13,200$ in total non-housing debt and $\$ 16,900$ in student debt, 
the same as those who had no help from parents. These levels of student debt are very similar to those estimated by Andreski, Kreisman and Schoeni (2015) who show that the estimates of student loans from the PSID TA study are similar to those in the National Postsecondary Student Aid Survey.

These descriptive findings suggest that parents may shelter their college-going children from some, although not most, of their post-college debt. At the same time, parents who help finance their children's college education may end up with more debt of their own, especially mortgage debt. In the next section, we outline an estimation strategy to assess whether these latter descriptive results are causal.

The specifications we use to examine the effect of whether a child went to college and whether parents helped finance college on the subsequent indebtedness of parents and their children differ from those in Sections 3 and 4. Here we focus on the direct effect of college attendance and parental financing decisions on the additional amount of debt parents and children accumulate. As we describe below, this requires some additional controls and creates new challenges for identifying causal relationships.

More precisely, let Attend $_{i j}$ be an indicator variable equal to 1 if child $j$ of parent $i$ attends college and zero otherwise, ${ }^{21}$ and define AttendFin $_{i j}$ to be the indicator variable equal to 1 if child $j$ attends college and parent $i$ provides funds to finance it and zero otherwise, ${ }^{22}$ We are interested in the effects of these variables on parents' and children's debt when the child reaches age 24 in year $t_{24_{j}}$, net of other factors. More precisely, for parents we seek to estimate the following specification for two sources of debt:

$$
\begin{aligned}
\text { Debt }_{\text {hit }_{24_{j}}}= & \beta_{n h 0}^{P}+\beta_{h 1}^{P} \text { Attend }_{i j}+\beta_{h 2}^{P} \text { AttendFin }_{i j}+\beta_{h 3}^{P} Y_{\text {imt }_{24_{j}}} \\
& +\boldsymbol{\beta}_{h 4}^{P} \boldsymbol{X}_{{i t_{24_{j}}}}+\phi_{h t_{24_{j}}}^{P}+\delta_{h m}^{P}+u_{h i t_{24_{j}}}^{P} .
\end{aligned}
$$

for Debt $_{h}=$ MortBal,OthDebt, $Y_{{i m t_{24}}_{j}}$ is the parents' income in year $t_{24_{j}}, \boldsymbol{X}_{i t_{24_{j}}}$ is a vector of

\footnotetext{
${ }^{21}$ Attend $_{i j}=1$ if either EduFin $1_{i j}=1$ or EduFin $2_{i j}=1$ and equals zero otherwise.

${ }^{22}$ That is, AttendFin ${ }_{i j}=$ EduFin $2_{i j}$.
} 
parent $i$ 's characteristics in that year, $\boldsymbol{M}_{m t_{24}}$ are the corresponding characteristics for parents' location $m$ at $t_{24_{j}}$ and $\phi_{t_{24_{j}}}^{P}$ and $\delta_{s}^{P}$ are year and the parents' county fixed effects, respectively. Included in $\boldsymbol{X}_{i t_{24}{ }_{j}}$ are the same characteristics described in Section 3.1 where all time-varying covariates are measured in year $t_{24_{j}}$ instead of year $t_{18_{j}}$ used in our previous analyses. In addition, we include non-housing wealth of the parent at age 24 , the value of the home measured at age 18 , and parental income at age 24 .

Similarly, for the children at age 24 , for parents we seek to estimate the following specification for their two sources of debt:

$$
\begin{aligned}
\text { Debt }_{h j t_{24_{j}}}= & \beta_{n h 0}^{C}+\beta_{h 1}^{C} \text { Attend }_{i j}+\beta_{h 2}^{C} \text { AttendFin }_{i j}+\beta_{h 3}^{C} Y_{j m t_{24_{j}}} \\
& +\boldsymbol{\beta}_{h 4}^{C} \boldsymbol{X}_{j t_{24_{j}}}+\phi_{h t_{24_{j}}}^{C}+\delta_{h m}^{C}+u_{h j t_{24_{j}}}^{C} .
\end{aligned}
$$

for Debt $h_{h}=$ OthDebt, StudentDebt, $Y_{j m t_{24_{j}}}$ is child $j$ 's income in in year $t_{24_{j}}, \boldsymbol{X}_{n t_{24_{j}}}$ is a vector of child $j$ 's characteristics at child age 24 , and $\phi_{t_{24}}^{C}$ and $\delta_{s}^{C}$ are year and the child's state-ofresidence fixed effects, respectively. Included in $\boldsymbol{X}_{n t_{24}}$ are all of the characteristics of the parent described in Section 3.1 where all time-varying covariates are measured in year $t_{24_{j}}$, along with an indicator variable for coresidence with a parent, an indicator variable if the child is married in year $t_{24_{j}}$, an indicator variable for whether the child is a head of household in year $t_{24_{j}}$, and family income of the child at age 24 .

Below, we present estimates of the effects of Attend and AttendFin in specifications in (15) and (16) using ordinary least squares (OLS). But, it is reasonable to presume that parents' and children's income when the child is age 24, $Y_{{\text {imt } t_{24}}}$ that is included in (15) and $Y_{j m t_{24_{j}}}$ in (16), respectively, are likely to be endogenous, especially given that these variables are contemporaneous with when we assess parents' and children's levels of debt. Furthermore, the decisions concerning whether a child went to college but parents did not help finance it $\left(\right.$ Attend $\left._{i j}=1\right)$ or parents did help finance it $\left(A t t e n d F i n_{i j}=2\right)$ may be correlated with the unobserved factors that make up $u_{h i t_{24_{j}}}^{P}$ and $u_{h i t_{24_{j}}}^{C}$ in these debt specifications. This would be the case if the unobserved determinants of the college and parental financing choices accounted for in the payoff 
functions in (5), made when the child was age 18, and those in (15) and (16) are common across time and/or were serially correlated.

To account for the potential endogeneity of parents' and children's income when the child is age 24 in the debt regressions, we follow the strategy we used to instrument parental income at age 18 in the college choice and financing specifications discussed in Section 3.2 and define as a new instrumental variable the local labor market variable $\Delta W_{m t_{24_{j}}}^{P}$, which is defined in the same way as $\Delta W_{m t_{18_{j}}}^{P}$ for the market, $m$, in which person $n(n=i$ for parents and $n=j$ for children) resides in year $t_{24_{j}}$. We also define an additional instrument which which measures the distance child $j$ was from the nearest a four-year public college in their county $m$ when child $j$ was age $18 .^{23}$

A plausible set of instruments for Attend and AttendFin in (15) and (16) would be to use the local market variables, $\Delta H P I_{m t_{18_{j}}}$ and $\Delta W_{m t_{18_{j}}}$, measured at $t_{18_{j}}$, that were used to instrument $H_{j m t_{18_{j}}}$ and $Y_{j m t_{18_{j}}}$ in the control function estimator of the college enrollment and transfers decisions, and the 2SLS estimation of the amount of the transfer and the graduation and college quality outcomes. We employed these instruments, along with $\Delta W_{m t_{24} j}^{P}$ and Dist4YrPub ${ }_{i j m}$, to instrument for Attend, AttendFin and $Y_{j^{2} t_{24} j_{j}}$ in a 2SLS estimation of the specifications in (15) and (16). But, the first stage results for both Attend and AttendFin in these specifications indicated very weak instruments, with the test statistics for the joint significance of these instruments for Attend and AttendFin never being greater than 9.8 and most of never being greater than 5.0. In contrast, and as reported in Appendix Table B.2, the first stage estimates for $Y_{j m t_{24}}$ using these same instruments produced test statistics greater than 22. Accordingly, in the analysis below, we report 2SLS results for the estimation of (15) and (16) in which we only account for the endogeneity of $Y_{j m t_{24}}$. Because of this, we take care not to over-interpret the 2SLS results presented below.

\footnotetext{
${ }^{23}$ Using PSID geocode data on the location of their parents' residence at that age and geocoded data from IPEDS on the location of all public universities, we constructed the variable, Dist4YrPub $b_{i j m}$, as the distance, in miles, to the nearest four-year public university. A comparable measure was used in Card (1995) and others as an instrument for schooling in the estimation of the returns to schooling.
} 


\subsection{Empirical Results}

Panel A of Table 8 presents the results of estimating the specification for parental debt in equation (15). We show estimates from OLS specifications in which college attendance and financing is taken as exogenous and from 2SLS specifications in which we instrument for the effects of parental income in year $t_{24_{j}}$. In these tables, we only display the effects of children attending college (Attend) and whether parents helped finance their child's college education (AttendFin) on parent levels of debt when their child was age 24. With respect to parents mortgage debt, both the OLS and the 2SLS results indicate that parents who provide children with a financial transfer for college have more outstanding mortgage debt six years after their child entered college, i.e., when their child is age 24 , relative to parents whose child did not attend college. The OLS and 2SLS results indicate that parents who help finance their child's college attendance have more mortgage debt, $\$ 15,930$ based on the OLS results and $\$ 15,920$ with the 2SLS. Furthermore, both of these effects are precisely estimated. And, parents whose child attends college without receiving a financial transfer from parents do not hold more mortgage debt than parents whose child did not attend college.

Panel A also includes estimates the effect of a child's college attendance and parental financing on the amounts of non-housing debt parents hold in year $t_{24_{j}}$. For both the OLS and the 2SLS results, we find that having a child who attends college increases parental non-housing debt when their child is age 24 relative to having a child who does not attend college $(\$ 3,460$ with OLS and $\$ 3,420$ with 2SLS), although these increases are much smaller than those for mortgage debt. Both of these effects are precisely estimated. With respect to the additional effect of parents helping to finance college (AttendFin), we find small positive effects on other debt, but neither the OLS or 2SLS estimates are statistically significant. As a result, one cannot reject the hypothesis that this source of debt does not differ between parents who provide financial transfers to their children to attend college those who do not.

In Panel B of Table 8 we present estimates of the effects of college attendance and parental financial support on the debt levels held by children at age 24 . With respect to both the OLS and 2SLS results, we find that children who attend college (Attend) have substantially higher student loan ( $\$ 14,430$ based on OLS and $\$ 14,290$ with 2 SLS) and other forms of debt ( $\$ 10,470$ 
with OLS and $\$ 10,420$ with 2 SLS) than children who do not attend college and these effects are precisely estimated. In contrast, children whose parents help to finance their college education do not hold less student debt or other forms of debt than children who attend college without parental financial support. These results suggest that there is not necessarily a reduction in student debt when parents provide financial support for college. One reason we may find similar levels of student debt among children whose parents finance and do not finance college is that students whose parents provide financial support for college are more likely to graduate and thus they pay for more total years of schooling. But, as noted at the end of the previous section, one must be cautious in interpreting these findings for the effects of college attendance and parental financing on parents' and children's subsequent levels of debt as causal, given that they do not account for the potential endogeneity of either Attend and AttendFin our 2SLS results.

\section{Conclusion}

This paper examines the influence of parental housing wealth and income on college attendance and parental financial support for college and on college graduation rates and quality of college attended. It also examines the ramifications of these decisions on the subsequent indebtedness of parents and children. We use data from the PSID, especially data in the 2013 Roster and Transfers Module on the incidence and amounts of parental financial support for college. We instrument for the potential endogeneity of parental housing wealth and income with changes in parents' local housing and labor market conditions to generate causal estimates of the effect of parental housing wealth and income on educational outcomes. We find that increases in parental income and wealth increase the likelihood of children attending college, largely because it increases parental provision of financial support. The effect of an increase in parental income on college enrollment is larger than the effect of an increase in parental wealth. But, parental wealth increases graduation rates, while parental income does not seem to have an effect on college graduation. We find that the effect of parental wealth on college graduation is related to parents taking out home equity loans which appear to have a large effect on the likelihood that a child graduates from college. We also find suggestive evidence that the decision to provide financial support for a child's schooling increases levels of parental mortgage debt. 
In contrast, students who attend college with financial support from parents do not have lower levels of student and other debt later in life than children who attend college without financial support.

These findings fill gaps in prior research by establishing that the mechanism through which increases in parental income and wealth affect college attendance is indeed through parental financial transfers. Our findings also complement recent work suggesting an increasingly important role for parental income in college attendance decisions. And, we provide the new evidence based on PSID data that the likelihood of children graduating from college increases with higher levels of parental wealth, likely due to the more complete data on children's college attainment gathered in the Roster and Transfers Module in the 2013 wave of the PSID. Finally, though our results about debt are more descriptive, they do indicate that parents who provide financial transfers to their children take on additional debt of their own. The increases in parental debt as a result of college financing decisions may simply reflect an efficient way to fund college tuition. Alternatively, this increase in parental debt may represent an intergenerational shifting of debt incurred with children going to college, one that represents a burden on parents that may adversely affect their later-life consumption or other measures of well-being. This is an important avenue for future research especially in light of the large increases in college tuition and in levels of student debt in recent years. 


\section{References}

Andreski, Patricia, Daniel Kreisman, and Robert F. Schoeni. 2015. "Comparing Estimates of Student Loans Measured in the PSID-TAS with the National Postsecondary Student Aid Survey." PSID Technical Series Paper \#15-02.

Belley, Philippe, and Lance Lochner. 2007. "The Changing Role of Family Income and Ability in Determining Educational Achievement." Journal of Human Capital, 1(1): 37-89.

Black, Dan, and Jeffrey A. Smith. 2004. "How Robust is the Evidence on the Effects of College Quality? Evidence from Matching." Journal of Econometrics, 121(1): 99-124.

Black, Dan, and Jeffrey A. Smith. 2006. "Estimating the Returns to College Quality with Multiple Proxies for Quality." Journal of Labor Economics, 24(3): 701-728.

Black, Dan, Jeffrey A. Smith, and Kermit Daniel. 2005. "College Quality and Wages in the United States." German Economic Review, 6(3): 415-443.

Bleemer, Zachary, Meta Brown, Donghoon Lee, Katherine Strair, and Wilbert van der Klaauw. 2017. "Echoes of Rising Tuition in Students' Borrowing, Educational Attainment, and Homeownership in Post-Recession America." Federal Reserve Bank of New York Staff Report No. 820, New York.

Blundell, Richard, and James L. Powell. 2003. "Endogeneity in Nonparametric and Semiparametric Regression Models." In Advances in Economics and Econonometrics: Theory and Applications, Eighth World Congress Volume., ed. M. Dewatripont, L.P. Hansen and S.J. Turnovsky, 312-357. Cambridge University Press.

Bound, John, and Sarah Turner. 2011. "Dropouts and Diplomas: The Divergence in Collegiate Outcomes." In Handbook of the Economics of Education. Vol. 4, , ed. Eric Hanushek, Stephen Machin and Ludger Woessmann, 573-613. Elsevier B. V.

Bound, John, Michael F. Lovenheim, and Sarah Turner. 2010. "Why Have College Completion Rates Declines? An Analysis of Changing Student Preparation and Collegiate Resources." American Economic Journal: Applied Economics, 2: 129-157.

Browning, Martin, Mette Gørtz, and Søren Leth-Petersen. 2013. "Housing Wealth and Consumption: A Micro Panel Study." The Economic Journal, 123(568): 401-428.

Cameron, Stephen, and Christopher Taber. 2004. "Estimation of Educational Borrowing Constraints using Returns to Schooling." Journal of Political Economy, 112: 132-182.

Cameron, Stephen, and James J. Heckman. 1998. "Life Cycle Schooling and Dynamic Selection Bias: Models and Evidence for Five Cohorts of American Males." Journal of Political Economy, 106: 262-333.

Cameron, Stephen, and James J. Heckman. 2001. "The Dynamics of Educational Attainment for Black, Hispanic, and White Males." Journal of Political Economy, 109: 455-99. 
Card, David. 1995. "Using Geographic Variation in College Proximity to Estimate the Returns to Schooling." In Aspects of Labour Market Behaviour: Essays in Honor of John Vanderkamp. , ed. Louis N. Christofides, E. Kenneth Grant and Robert Swidinsky, 201-221. University of Toronto Press.

Carroll, Christopher D., Misuzu Otsuka, and Jiri Slacalek. 2011. "How Large are Housing and Financial Wealth Effects? A New Approach." Journal of Money, Credit and Banking, 43(1): 55-79.

College Board. 2015. "Trends in Student Aid 2015." trends.collegeboard.org.

College Board. 2017. "Trends in Student Aid 2017." trends.collegeboard.org.

Cooper, Daniel, and Christine Wang. 2014. "Student Loan Debt and Economic Outcomes." Unpublished manuscript, Federal Reserve Bank of Boston.

Cooper, Daniel, and Maria José Luengo-Prado. 2015. "House Price Growth when Children are Teenagers: A Path to Higher Earnings?" Journal of Urban Economics, 86: 54-72.

Dillon, Eleanor W., and Jeffrey Andrew Smith. 2017a. "Determinants of the Match between Student Ability and College Quality." Journal of Labor Economics, 35(1): 45-66.

Dillon, Eleanor W., and Jeffrey A. Smith. 2017b. "The Consequences of Academic Match between Students and Colleges." CESIfo Working Paper No. 6344.

Faber, Jacob W., and Peter M. Rich. forthcoming. "Financially Overextended: College Attendance as a Contributor to Foreclosures During the Great Recession." Demography.

Kane, Thomas J., and Cecilia Elena Rouse. 1995. "Labor-Market Returns to Two- and Four-Year College." American Economic Review, 85(3): 600-614.

Keane, Michael, and Kenneth I. Wolpin. 2001. "The Effect of Parental Transfers and Borrowing Constraints on Educational Attainment." International Economic Review, 42: 10511103.

Lochner, Lance J., and Alexander Monge-Naranjo. 2011. "The Nature of Credit Constraints and Human Capital." American Economic Review, 101(6): 2487-2529.

Lochner, Lance J., and Alexander Monge-Naranjo. 2012. "Credit Constraints in Education." Annual Review of Economics, 4(1): 225-256.

Lochner, Lance, Todd Stinebrickner, and Utku Suleymanoglu. 2018. "Parental Support, Savings and Student Loan Repayment." NBER Working Paper 24863.

Lovenheim, Michael F. 2011. "The Effect of Liquid Housing Wealth on College Enrollment." Journal of Labor Economics, 29(4): 741-771.

Lovenheim, Michael F., and C. Lockwood Reynolds. 2013. "The Effect of Housing Wealth on College Choice: Evidence from the Housing Boom." Journal of Human Resources, 48(1): 135 . 
McFarland, J., B. Hussar, C. de Brey, T. Snyder, X. Wang, S. Wilkinson-Flicker, S. Gebrekristos, J. Zhang, A. Rathbun, A. Barmer, F. Bullock Mann, and S. Hinz. 2017. The Condition of Education, 2017. U.S. Department of Education, National Center for Education Statistics.

Mezza, Alvaro A., Daniel R. Ringo, Shane M. Sherlund, and Kamila Sommer. 2015. "On the Effect of Student Loans on Access to Homeownership." Board of Governors, Federal Reserve System, Finance and Economics Discussion Series 2016-010, Washington.

Paiella, Monica, and Luigi Pistaferri. 2017. "Decomposing the Wealth Effect on Consumption." Review of Economics and Statistics, 99(4): 710-721.

Petrin, Amil, and Kenneth Train. 2010. "A Control Function Approach to Endogeneity in Consumer Choice Models." Journal of Marketing Research, XLVII: 3-13.

Rothstein, Jesse, and Cecilia Elena Rouse. 2011. "Constrained after College: Student Loans and Early-Career Occupational choices." Journal of Public Finance, 95: 149-163.

SallieMae. 2017. "How America Pays for College 2017." Sallie Mae Bank.

Schoeni, Robert F., Suzanne M. Bianchi, V. Joseph Hotz, Judith A. Seltzer, and Emily E. Wiemers. 2015. "Intergenerational Transfers and Rosters of the Extended Family: A new substudy of the Panel Study of Income Dynamics." Longitudinal and Life Course Studies, 6(3): 319-330.

Scott, Marc, Thomas Bailey, and Greg Kienzl. 2006. "Relative Success? Determinants of College Graduation Rates in Public and Private Colleges in the U.S." Research in Higher Education, 47(3): 249-279.

Stock, James H., and Douglas Staiger. 1997. "Instrumental Variables Regression with Weak Instruments." Econometrica, 65(3): 557-586.

Wooldridge, Jeffrey M. 2014. "Quasi-Maximum Likelihood Estimation and Tests for Nonlinear Models with Endogenous Explanatory Variables." Journal of Econometrics, 182: 226234. 
Table 1. Sample Sizes

\begin{tabular}{lr}
\hline \hline Samples & $N$ \\
\hline Parent-Child Pairs for Analyses of: & \\
Child's College Choices (EduFin0, EduFin1, EduFin2) \& Amount of Transfer & 2,866 \\
Whether Child Graduated from College & 1,418 \\
College Tuition Costs, Conditional on Attending & 856 \\
Whether Child attended 4-year College, Conditional on on Attending & 854 \\
Whether attended Private College, Conditional on attending 4-Yr College & 704 \\
College Quality Index, Conditional on attending 4-Yr College & 705 \\
Parent-Child Pairs when Child at age 24 for Analyses of: ${ }^{1}$ & \\
Parents' Mortgage Debt & 2,580 \\
Parents' 'Other' Debt & 2,571 \\
Children's 'Other' Debt & 1,756 \\
Children's Student Loan Debt & 1,196 \\
\hline${ }^{1}$ Data on the debt of children at or near when they are age 24 is obtained from either the regular PSID \\
survey or from the the Transition to Adulthood (TA) survey which covers children who are age 18 or older \\
regardless of whether they have become the head of their own household.
\end{tabular}


TABLE 2. Child's College Enrollment Choices \& Parental Transfers for College among Homeowning Parents \& College-Age Children in PSID, 1997-2015

\begin{tabular}{lr}
\hline \hline Variable & Mean \\
\hline Child's College Enrollment Choices: & \\
Child does not enroll (EduFin0) & 0.44 \\
Child enrolls, no transfer (EduFin1) & 0.30 \\
Child enrolls, transfer (EduFin2) & 0.26 \\
Amount of Transfer (CollTrans) & $\$ 0.78$ \\
\hline
\end{tabular}

${ }^{1}$ Statistics weighted using PSID family weights.

${ }^{2}$ Conditional on those students who attended college at age 18. Dollar amount is in $10 \mathrm{~K}$ of $2013 \$$. 
TABle 3. Parents' Net Equity, Parental Income by College Attendance and Parental Financing when Child was Age $18^{1}$

\begin{tabular}{|c|c|c|c|c|}
\hline & $\begin{array}{c}\text { Full } \\
\text { Sample }\end{array}$ & $\begin{array}{l}\text { EduFin0 } \\
\text { (No Coll) }\end{array}$ & $\begin{array}{c}\text { EduFin1 } \\
\text { (Coll, but } \\
\text { No Transfer) }\end{array}$ & $\begin{array}{c}\text { EduFin2 } \\
\text { (Coll \& } \\
\text { Transfer) } \\
\end{array}$ \\
\hline Parents' Net Equity $\left(H_{i m t_{18_{j}}}\right)$ & $\$ 5.73$ & $\$ 2.90$ & $\$ 5.02$ & $\$ 11.36$ \\
\hline Parents' Income $\left(Y_{i m t_{18_{j}}}\right)$ & $\$ 7.69$ & $\$ 5.28$ & $\$ 7.51$ & $\$ 12.03$ \\
\hline
\end{tabular}

${ }^{1}$ Statistics weighted using PSID family weights. Dollar amounts are in $10 \mathrm{~K}$ of $2013 \$$. 
TABLE 4. Marginal Effects of Changes in Wealth and Income on College \& Financing Choices and Amount of Financing ${ }^{1}$

\begin{tabular}{|c|c|c|c|c|c|}
\hline \multirow[b]{2}{*}{ Variable } & \multicolumn{3}{|c|}{ College and Financing Choices: } & \multicolumn{2}{|c|}{ Amount of Transfer: } \\
\hline & $\begin{array}{l}\text { EduFin0 } \\
\text { (No Coll) } \\
(1)\end{array}$ & $\begin{array}{c}\text { EduFin1 } \\
\text { (Coll, but } \\
\text { No Transfer) } \\
(2)\end{array}$ & $\begin{array}{c}\text { EduFin2 } \\
\text { (Coll \& } \\
\text { Transfer) } \\
(3)\end{array}$ & $\begin{array}{l}\text { OLS } \\
(4)\end{array}$ & $\begin{array}{c}2 \mathrm{SLS}^{2} \\
(5)\end{array}$ \\
\hline \multicolumn{6}{|c|}{ Panel A. Schooling and Financing Choice, Multinomial Logit } \\
\hline$H_{i m t_{18_{j}}}$ & $\begin{array}{c}-0.0039^{*} \\
(0.0021)\end{array}$ & $\begin{array}{c}0.0003 \\
(0.0015)\end{array}$ & $\begin{array}{l}0.0036^{* * *} \\
(0.0012)\end{array}$ & & \\
\hline$Y_{i m t_{18_{j}}}$ & $\begin{array}{c}-0.0196^{* * *} \\
(0.0032)\end{array}$ & $\begin{array}{l}0.0085^{* * *} \\
(0.0028)\end{array}$ & $\begin{array}{l}0.0111^{* * *} \\
(0.0026)\end{array}$ & & \\
\hline$N$ & & & 2.651 & & \\
\hline \multicolumn{6}{|c|}{ Panel B. Schooling and Financing Choice, Control Function ${ }^{2}$} \\
\hline$H_{i m t_{18_{j}}}$ & $\begin{array}{r}-0.0035 \\
(0.0051)\end{array}$ & $\begin{array}{r}-0.0022 \\
(0.0045)\end{array}$ & $\begin{array}{l}0.0058^{* *} \\
(0.0028)\end{array}$ & & \\
\hline$Y_{i m t_{18_{j}}}$ & $\begin{array}{c}-0.0214^{* * *} \\
(0.0056)\end{array}$ & $\begin{array}{c}0.0045 \\
(0.0046)\end{array}$ & $\begin{array}{l}0.0169^{* * *} \\
(0.0045)\end{array}$ & & \\
\hline$N$ & & 2.645 & & & \\
\hline \multicolumn{6}{|c|}{ Panel C. Transfer Amounts, OLS and $2 S L S$} \\
\hline$H_{i m t_{18_{j}}}$ & & & & $\begin{array}{l}0.0316^{* * *} \\
(0.0118)\end{array}$ & $\begin{array}{c}0.0205 \\
(0.0199)\end{array}$ \\
\hline$Y_{i m t_{18_{j}}}$ & & & & $\begin{array}{l}0.0769^{* * *} \\
(0.0162)\end{array}$ & $\begin{array}{l}0.1510^{* * *} \\
(0.0357)\end{array}$ \\
\hline$R^{2}$ & & & & 0.400 & 0.375 \\
\hline$N$ & & & & 2.551 & 2.551 \\
\hline
\end{tabular}

${ }^{1}$ Standard errors in parentheses. ${ }^{* * *} p<0.01,{ }^{* *} p<0.05,{ }^{*} p<0.1$.

The explanatory variables included in these regressions are as follows: characteristics of parents when child was 18 (age, marital status, family structure, education, sex, race), sex of child, average weighted wage rates for young people, employment rate when the child was 18 , the high school and college wage premium, year fixed effects, and state fixed effects.

${ }^{2}$ The variables $H_{i m t_{18_{j}}}$ and $Y_{i m t_{18_{j}}}$ were treated as endogenous in the control function and 2SLS specifications and were instrumented with $\Delta H P I_{m t_{18_{j}}}$ and $\Delta W_{m t_{18_{j}}}^{P}$. See Section 3.2 for a description of these instruments. 
TABle 5. College Graduation, Annual Tuition, Types of College and College Quality ${ }^{1}$

\begin{tabular}{|c|c|c|c|c|}
\hline Variable & $\begin{array}{c}\text { Full } \\
\text { Sample }\end{array}$ & $\begin{array}{c}\text { Attended } \\
\text { College }\end{array}$ & $\begin{array}{c}\text { EduFin1 } \\
\text { (Coll, but } \\
\text { No Transfer) }\end{array}$ & $\begin{array}{c}\text { EduFin2 } \\
\text { (Coll \& } \\
\text { Transfer) }\end{array}$ \\
\hline Graduated from College $(G r a d)^{2}$ & 0.27 & 0.40 & 0.37 & 0.43 \\
\hline Annual Tuition (Tuition) $)^{2}$ & & $\$ 9,608$ & $\$ 7,776$ & $\$ 10,924$ \\
\hline Attended 4-Year College $(4 Y r C o l l)^{2}$ & & 0.82 & 0.76 & 0.87 \\
\hline Attended Private College (Private $)^{3}$ & & 0.33 & 0.31 & 0.35 \\
\hline College Quality Index (Quality) ${ }^{3}$ & & 0.33 & 0.07 & 0.49 \\
\hline
\end{tabular}

${ }^{1}$ Statistics weighted using PSID family weights. Tuition amounts are in $2013 \$$.

${ }^{2}$ Conditional on those students who attended college at age 18 .

${ }^{3}$ Conditional on those who attended a 4-year college at age 18 . 
TABLE 6. Effects of Parents' Home Equity and Family Income on Probability of Child Graduating from College \& the Quality of the College their Children Attended ${ }^{1}$

\begin{tabular}{|c|c|c|c|c|}
\hline Variable & $\begin{array}{c}\text { OLS } \\
(1)\end{array}$ & $\begin{array}{l}\text { 2SLS }^{2} \\
(2) \\
\end{array}$ & $\begin{array}{c}\text { OLS } \\
(3) \\
\end{array}$ & $\begin{array}{c}\text { 2SLS }^{2} \\
(4)\end{array}$ \\
\hline Panel $A$. & \multicolumn{4}{|c|}{ Graduate from College: ${ }^{2}$} \\
\hline$H_{i m t_{18_{j}}}$ & $\begin{array}{c}0.000 \\
(0.002)\end{array}$ & $\begin{array}{c}0.011^{*} \\
(0005)\end{array}$ & & \\
\hline$Y_{i m t_{18_{j}}}$ & $\begin{array}{c}0.004^{*} \\
(0.002)\end{array}$ & $\begin{array}{c}0.006 \\
(0.004)\end{array}$ & & \\
\hline $\begin{array}{l}R^{2} \\
N\end{array}$ & $\begin{array}{l}0.291 \\
1,322\end{array}$ & $\begin{array}{c}0.266 \\
1,322\end{array}$ & & \\
\hline Panel B. & \multicolumn{2}{|c|}{ Annual Tuition Costs ${ }^{2}$} & \multicolumn{2}{|c|}{ Attended 4-Year College 2} \\
\hline$H_{i m t_{18_{j}}}$ & $\begin{array}{c}99.943^{*} \\
(51.204)\end{array}$ & $\begin{array}{c}112.302 \\
(148.424)\end{array}$ & $\begin{array}{c}0.003 \\
(0.002)\end{array}$ & $\begin{array}{c}-0.001 \\
(0.005)\end{array}$ \\
\hline$Y_{i m t_{18_{j}}}$ & $\begin{array}{c}19.887 \\
(63.967)\end{array}$ & $\begin{array}{c}4.892 \\
(164.709)\end{array}$ & $\begin{array}{c}-0.001 \\
(0.003)\end{array}$ & $\begin{array}{c}0.003 \\
(0.006)\end{array}$ \\
\hline & $\begin{array}{c}0.397 \\
786\end{array}$ & $\begin{array}{c}0.397 \\
786\end{array}$ & $\begin{array}{c}0.288 \\
793\end{array}$ & $\begin{array}{c}0.280 \\
793\end{array}$ \\
\hline Panel $C$. & \multicolumn{2}{|c|}{ Attended Private College 3} & \multicolumn{2}{|c|}{ College Quality Index ${ }^{3}$} \\
\hline$H_{i m t_{18_{j}}}$ & $\begin{array}{c}0.002 \\
(0.003)\end{array}$ & $\begin{array}{c}-0.007 \\
(0.009)\end{array}$ & $\begin{array}{c}0.015 \\
(0.010)\end{array}$ & $\begin{array}{c}-0.024 \\
(0.026)\end{array}$ \\
\hline$Y_{i m t_{18_{j}}}$ & $\begin{array}{c}-0.002 \\
(0.003)\end{array}$ & $\begin{array}{c}0.002 \\
(0.007)\end{array}$ & $\begin{array}{l}0.020^{*} \\
(0.011)\end{array}$ & $\begin{array}{c}0.037 \\
(0.035)\end{array}$ \\
\hline$R^{2}$ & 0.300 & 0.283 & 0.343 & 0.304 \\
\hline$N$ & 653 & 653 & 640 & 640 \\
\hline
\end{tabular}

${ }^{1}$ Standard errors in parentheses. ${ }^{* * *} p<0.01,{ }^{* *} p<0.05,{ }^{*} p<0.1$.

The explanatory variables included in these regressions are as follows: characteristics of parents when child was 18 (age, marital status, family structure, education, sex, race), sex of child, average weighted wage rates for young people, employment rate when the child was 18 , whether the child is a head or wife at age 24 , the high school and college wage premium, year fixed effects, and county fixed effects.

2 The variables $H_{i m t_{18_{j}}}$ and $Y_{i m t_{18_{j}}}$ were treated as endogenous in the 2SLS specifications and were instrumented with $\Delta H P I_{m t_{18_{j}}}$ and $\Delta W_{m t_{18_{j}}}^{P}$. See Section 3.2 for a description of these instruments.

${ }^{2}$ Conditional on those students who attended college at age 18 .

${ }^{3}$ Conditional on those who attended a 4-year college at age 18 . 
TABle 7. Parents' \& Child's Debt when Child Age 24, by College Attendance and Financing Decisions ${ }^{1}$

\begin{tabular}{lrrrr}
\hline \hline & $\begin{array}{c}\text { Full } \\
\text { Sample }\end{array}$ & $\begin{array}{r}\text { EduFin0 } \\
\text { (No Coll) }\end{array}$ & $\begin{array}{r}\text { EduFin1 } \\
\text { (Coll, No } \\
\text { Transfer) }\end{array}$ & $\begin{array}{r}\text { EduFin2 } \\
\text { (Coll \& } \\
\text { Transfer) }\end{array}$ \\
\hline Variable & & & & \\
Parents' Debt: & $\$ 6.95$ & $\$ 4.54$ & $\$ 5.95$ & $\$ 10.01$ \\
$\quad \begin{array}{l}\text { Mortgage Debt (MortBal) } \\
\text { Other Debt (OthDebt) }\end{array}$ & $\$ 1.34$ & $\$ 0.84$ & $\$ 1.35$ & $\$ 1.80$ \\
Child's Debt: & & & & \\
Other Debt (OthDebt) & $\$ 1.23$ & $\$ 0.80$ & $\$ 1.50$ & $\$ 1.32$ \\
Student Debt (StudentDebt) & $\$ 1.26$ & $\$ 0.22$ & $\$ 1.68$ & $\$ 1.69$ \\
\hline${ }^{1}$ Statistics weighted using PSID family weights. All debt amounts are in 10K of 2013\$.
\end{tabular}


TABle 8. Effects of Child's College Attendance and Parental Financing on Parents' and Child's Indebtedness when Child is Age $24^{1}$

\begin{tabular}{|c|c|c|c|c|}
\hline Variable & $\begin{array}{l}\text { OLS } \\
(1)\end{array}$ & $\begin{array}{l}2 \mathrm{SLS}^{2} \\
(2)\end{array}$ & $\begin{array}{l}\text { OLS } \\
(3)\end{array}$ & $\begin{array}{l}2 \mathrm{SLS}^{2} \\
(4)\end{array}$ \\
\hline $\begin{array}{l}\text { Panel A. Parents' Debt: }{ }^{3} \\
\text { No College (base category) }\end{array}$ & \multicolumn{2}{|c|}{ Mortgage Debt } & \multicolumn{2}{|c|}{ Other Debt } \\
\hline Attends College (Attend) & $\begin{array}{l}-0.602 \\
(0.466)\end{array}$ & $\begin{array}{l}-0.604 \\
(0.467)\end{array}$ & $\begin{array}{l}0.346^{* *} \\
(0.163)\end{array}$ & $\begin{array}{l}0.342^{* *} \\
(0.155)\end{array}$ \\
\hline Attends with Financing (AttendFin) & $\begin{array}{l}1.593^{* * *} \\
(0.568)\end{array}$ & $\begin{array}{l}1.592^{* * *} \\
(0.533)\end{array}$ & $\begin{array}{c}0.235 \\
(0.184)\end{array}$ & $\begin{array}{c}0.800 \\
(0.695)\end{array}$ \\
\hline $\begin{array}{l}R^{2} \\
N\end{array}$ & $\begin{array}{l}0.468 \\
2,270\end{array}$ & $\begin{array}{l}0.486 \\
2,270\end{array}$ & $\begin{array}{l}0.231 \\
2,268\end{array}$ & $\begin{array}{l}0.231 \\
2,268\end{array}$ \\
\hline $\begin{array}{l}\text { Panel B. Child's Debt: }{ }^{4} \\
\text { No College (base category) }\end{array}$ & \multicolumn{2}{|c|}{ Student Loan Debt } & \multicolumn{2}{|c|}{ Other Debt } \\
\hline Attends College (Attend) & $\begin{array}{l}1.443^{* * *} \\
(0.211)\end{array}$ & $\begin{array}{l}1.429 * * * \\
(0.193)\end{array}$ & $\begin{array}{l}1.047^{* * *} \\
(0.247)\end{array}$ & $\begin{array}{l}1.042^{* * * *} \\
(0.244)\end{array}$ \\
\hline Attends with Financing (AttendFin) & $\begin{array}{l}-0.116 \\
(0.334)\end{array}$ & $\begin{array}{l}-0.102 \\
(0.306)\end{array}$ & $\begin{array}{l}-0.307 \\
(0.225)\end{array}$ & $\begin{array}{l}-0.307 \\
(0.211)\end{array}$ \\
\hline $\begin{array}{l}R^{2} \\
N\end{array}$ & $\begin{array}{l}0.286 \\
1,152\end{array}$ & $\begin{array}{l}0.285 \\
1,152\end{array}$ & $\begin{array}{l}0.108 \\
1,587\end{array}$ & $\begin{array}{l}0.108 \\
1,587\end{array}$ \\
\hline $\begin{array}{l}1 \text { Standard errors in parentheses. } * * * p<0.01 \\
2013 \$ \text {. } \\
2 \text { The variables Parental Income in year } t_{24_{j}} \\
\text { in year } t_{24_{j}}\left(Y_{j m t_{24, j}}\right) \text { for Panel B specification } \\
\text { and were instrumented with } \Delta H P I_{m t_{18_{j}}}, \Delta H \\
\text { and } 5.1 \text { for descriptions of these instruments. } \\
3 \text { The explanatory variables included in Panel } \\
\text { when child was } 24 \text { (age, marital status, family } \\
\text { wealth of the parent when the child is } 24 \text {, va } \\
\text { effects. } \\
{ }^{4} \text { The explanatory variables included in Panel } \\
\text { when child was } 14 \text { (age, marital status, famil } \\
\text { the child is a head or wife at age } 24 \text {, whether } \\
\text { fixed effects. }\end{array}$ & $\begin{array}{l}{ }^{* *} p<0.05 \\
\left.Y_{\text {imt }_{24, j}}\right) \text { for } \\
\text { S were treate } \\
m t_{18_{j}}, \Delta W_{m}^{P} \\
\text { A regressior } \\
\text { structure, ed } \\
\text { lue of home } \\
\text { B regressior } \\
\text { y structure, } \\
\text { he child is } m\end{array}$ & $\begin{array}{l}{ }^{*} p<0.1 . \text { A } \\
\text { anel A spec } \\
\text { as endogen } \\
\text { and Dist } \\
\text { are as follo } \\
\text { cation, sex, } \\
t \text { 18, year } f \\
\text { are as follo } \\
\text { lucation, sex }\end{array}$ & $\begin{array}{l}\text { ebt amour } \\
\text { tions and } \\
\text { in the } 2 \mathrm{SI} \\
P u b_{i j m} \text {. } \\
\text { character } \\
\text { effects, a } \\
\text { character } \\
\text { ce), sex o }\end{array}$ & $\begin{array}{l}\text { tre in } 10 \mathrm{~K} \text { of } \\
\text { ild's Income } \\
\text { pecifications } \\
\text { Sections } 3.2 \\
\text { is of parents } \\
\text { l, non-equity } \\
\text { county fixed } \\
\text { is of parents } \\
\text { ild, whether }\end{array}$ \\
\hline
\end{tabular}




\section{Appendix A Descriptive Statistics for Demoographic Cha- racteristics of Parents and their Children}

TABle A.1. Characteristics of Homeowning Parents \& College-Age Children in PSID, 1997-2015

\begin{tabular}{lr}
\hline \hline Variable & Mean \\
\hline Parent Characteristics when Child was Age 18: & \\
Parent married/cohabiting & 0.70 \\
Parent HH Headed by Male & 0.82 \\
Number of children under 16 in parent HH & 0.87 \\
Age of parent House Head & 45.58 \\
Parents Non-White & 0.29 \\
Parent's Education: & \\
High school or less & 0.21 \\
Some College & 0.51 \\
College graduate & 0.28 \\
Child Characteristics: & \\
Sex of child (male=1) & 0.48 \\
Year child turned 18 & \\
${ }^{1}$ Statistics weighted using PSID family weights. & \\
${ }^{2}$ The range of years in which children turned age 18 is 1998-2015.
\end{tabular}




\section{Appendix B F-Tests for Weak Instruments in First-Stage Regressions for Control Function and IV Estimators}

Below we provide statistics for F-tests of the joint significance of the instrumental variables in the first-stage regressions for the control function and 2SLS estimators used in the various analyses presented in the paper. In the Table below, we indicate the tables to which the test statistics of the first-stage regressions correspond and the instrumental variables used in these regressions. We note that F-test statistics with values less than 10 for first-stage regressions are considered evidence of weak instruments (Stock and Staiger, 1997).

TABle B.1. F-Tests of Joint Significance of Instruments in First Stage Regressions $^{1}$

\begin{tabular}{|c|c|c|c|c|}
\hline Dependent Variable: & $Y_{i m t_{18, j}}$ & $H_{i m t_{18, j}}$ & $Y_{i m t_{18, j}}$ & $H_{i m t_{18, j}}$ \\
\hline \multicolumn{5}{|c|}{ First Stage Regressions for Results in Table 4: } \\
\hline F-test & 20.34 & 73.53 & 17.16 & 64.05 \\
\hline$R^{2}$ & 0.361 & 0.524 & 0.459 & 0.573 \\
\hline \multicolumn{5}{|c|}{$\begin{array}{l}\text { First Stage Regressions for Results in Table 6: } \\
\text { Graduate from College }{ }^{2}\end{array}$} \\
\hline F-test & 61.30 & 35.02 & & \\
\hline \multirow[t]{2}{*}{$R^{2}$} & 0.558 & 0.573 & & \\
\hline & \multicolumn{2}{|c|}{ Annual Tuition Costs ${ }^{2}$} & \multicolumn{2}{|c|}{ Attended 4-Year College ${ }^{2}$} \\
\hline F-test & 44.24 & 11.89 & 43.80 & 12.04 \\
\hline \multirow[t]{2}{*}{$R^{2}$} & 0.611 & 0.636 & 0.610 & 0.637 \\
\hline & \multicolumn{2}{|c|}{ Attended Private College ${ }^{3}$} & \multicolumn{2}{|c|}{ College Quality Index ${ }^{3}$} \\
\hline F-test & 27.95 & 12.83 & 28.28 & 12.65 \\
\hline$R^{2}$ & 0.624 & 0.635 & 0.623 & 0.635 \\
\hline
\end{tabular}

${ }^{1}$ The instruments used in all of these regressions and for which the F-tests apply are: $\Delta H P I_{m t_{18_{j}}}$ and $\Delta W_{m t_{18_{j}}}^{P}$.

2 These regressions are for children who attended college at age 18 .

${ }^{3}$ These regressions are for children who attended a 4-year college at age 18. 
TABle B.2. F-Tests of Joint Significance of Instruments in First Stage Regressions

\begin{tabular}{|c|c|}
\hline Dependent Variable: & $Y_{n m t_{24}}{ }^{1}$ \\
\hline \multicolumn{2}{|c|}{ First Stage Regressions for Results in Panel A of Table $8:^{2}$} \\
\hline \multicolumn{2}{|c|}{ Parents' Mortgage Debt at $t_{24_{j}}$} \\
\hline $\begin{array}{l}\text { F-test } \\
R^{2}\end{array}$ & $\begin{array}{l}22.36 \\
0.789\end{array}$ \\
\hline \multicolumn{2}{|c|}{ Parents' Other Debt at $t_{24_{j}}$} \\
\hline $\begin{array}{l}\text { F-test } \\
R^{2}\end{array}$ & $\begin{array}{l}22.18 \\
0.789\end{array}$ \\
\hline \multicolumn{2}{|c|}{ First Stage Regressions for Results in Panel B of Table $8:^{3}$} \\
\hline $\begin{array}{l}\text { F-test } \\
R^{2}\end{array}$ & $\begin{array}{r}124.60 \\
0.849\end{array}$ \\
\hline \multicolumn{2}{|c|}{ Child's Other Debt at $t_{24_{j}}$} \\
\hline $\begin{array}{l}\text { F-test } \\
R^{2}\end{array}$ & $\begin{array}{r}181.30 \\
0.811\end{array}$ \\
\hline \multicolumn{2}{|c|}{$\begin{array}{l}1 \text { The } n \text { subscript for } Y_{n m t_{24}}=i \text { for parents and }=j \text { for child. } \\
{ }^{2} \text { The instruments used in the parents' debt regressions and for } \\
\text { which the F-tests apply are: } \Delta H P I_{m t_{18_{j}}}, \Delta W_{m t_{1_{j}}}^{P}, \Delta W_{m t_{24_{j}}}^{P} \text { and } \\
D i s t 4 Y r P u b_{i j m} \text {. } \\
{ }^{3} \text { The instruments used in the child's debt regressions and for } \\
\text { which the F-tests apply are: } \Delta H P I_{m t_{1 \beta_{j}}}, \Delta W_{m t_{1_{j}}}^{P}, \Delta W_{m t_{24_{j}}}^{C} \text { and } \\
\text { Dist } 4 Y r P u b_{i j m} \text {. }\end{array}$} \\
\hline
\end{tabular}




\section{Appendix C Parents' Home Equity Loans when Child Age 18 and their Impact on College Gra- duation}

In this Appendix, we present an alternative version of the results for whether a parents' child graduated from college in Panel A of in Table 6 in which we include an indicator variable for whether the parents had a home equity loan when their child wage age 18 to the OLS and 2SLS regressions. (This indicator variable, HEquityLoan ${ }_{i m t_{18_{j}}}$, is equal to 1 if the parent had a home equity loan when child $j$ was age 18 and equal to 0 otherwise.) The results are displayed in Table C.1.

TABle C.1. Effects of Parents' Home Equity, Family Income, and Whether Parent had Home Equity Loan when Child was Age 18 on Whether Child Graduated from College, for College Attendees ${ }^{1}$

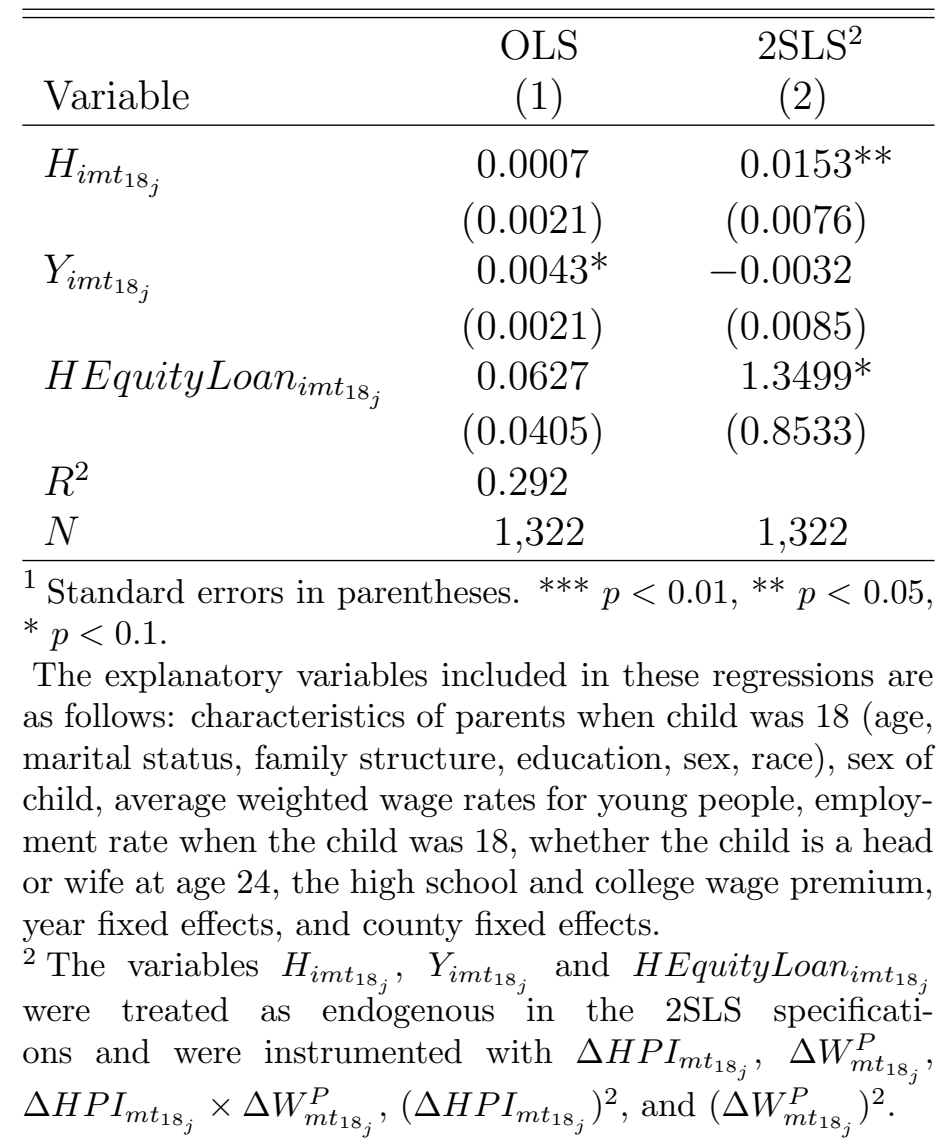

